\title{
GEOLOGY AND STRUCTURE OF THE GUANIAMO DIAMONDIFEROUS KIMBERLITE SHEETS, SOUTH-WEST VENEZUELA
}

\author{
DOMINIC MARK DERENZY CHANNER ${ }^{1}$, ANDREI EGOROV ${ }^{1} \&$ FELIX KAMINSKY ${ }^{2}$
}

\begin{abstract}
Guaniamo is the first kimberlite province identified in the Guayana Shield and is a new type of primary diamond deposit: a system of layered kimberlite sheets. Discovered kimberlites have been dated at between 840 and 710 Ma. They occur as at least eight discordant sheets, with vertical sheet separations of 50 to $125 \mathrm{~m}$, and cut mid-Proterozoic quartz diorite, granodiorite, gabbro and lamprophyre. Diamonds were found in all the sheets with an average grade of $1.5 \mathrm{cts} / \mathrm{t}$ and an average diamond value of US\$50-60/ct. The sheets occupy a region about $10 \mathrm{~km}$ along a north - westerly strike and are punctuated by short breaks or fracture zones over a few hundred meters. The sheets occupy a zone some $5 \mathrm{~km}$ wide, dipping at 5 to 20 degrees, and have a proven down dip extent of at least $1 \mathrm{~km}$. The sheets contain an estimated resource of 45 million tonnes of kimberlite. Sheet thickness varies from a few $\mathrm{cm}$ to $3.7 \mathrm{~m}$. Similarities in diamond type (greater than $86 \%$ eclogitic) and diamond indicator mineral chemistry suggest a common source for all the sheets. Sheet contacts with host rocks are sharp, and thin veins of kimberlite-related alteration in adjacent wall rock are common. During kimberlite emplacement, fractures were opened by magma pressure, and kimberlite was forcefully emplaced. North - east trending cross faults (e.g., Milagro, Los Indios, La Ceniza, Puente Palo) create a block mosaic and are associated with structural lows in kimberlite sheets and increased sheet thickness; they are the most likely locations for feeder dikes or pipes within the kimberlite sheet area. The Guaniamo sheets show structural similarities to kimberlite sheets in Greenland and Canada and diabase sheets elsewhere.
\end{abstract}

Keywords: kimberlite, diamond, sheet, Guaniamo, Venezuela.

INTRODUCTION The Guaniamo area is located in western Bolivar State, Venezuela, and is one of the most promising diamondiferous areas in South America (Fig. 1). Diamonds have been mined there since they were discovered in the alluvium of the Quebrada Grande River and its tributaries in 1968 (Curtis 1975, Baptista \& Svisero 1978). According to official data, the placer deposits have produced approximately 15 million carats of diamonds, but the actual production may have reached 30 million carats. Stones of up to 40 carats have been reported.

It was originally thought that the 1.7-1.9 Ga Roraima sediments were the source of the Venezuelan diamond placer deposits (Reid 1974). The Pre-Cambrian shield region of southern Venezuela was long considered to be non-prospective for diamondiferous kimberlites: the geology is mostly Proterozoic and areas of Archean rocks are relatively small and rare (e.g., the Imataca complex), and the main part of the Guayana Shield was metamorphosed and deformed during the Trans-Amazonian orogeny (2.15-1.96 Ga).

However, diamondiferous, tropically weathered, kimberlite sheets (i.e., discordant horizontal dikes, see Howard 1991) were discovered by Baxter - Brown, Cooper, and Drew within the Quebrada Grande river basin in 1982. Initially they were described as dikes, veins, small pipes and stocks, and were dated at $1732 \pm 0.82 \mathrm{Ga}$ (Nixon 1988. Nixon et al. 1992, 1995). These data seemed to be in good agreement with the idea proposed by Reid (1974) and supported by Gibbs \& Barron (1993), that the Roraima clastic strata played the role of an intermediate collector for diamonds in placer deposits. But recent studies of Guaniamo diamonds (Kaminsky et al. 1998a, 2000) demonstrated their origin from local sources, not from intermediate collectors, and kimberlite age determinations from fresh, unweathered specimens showed a significantly younger radiometric age.

Petrographic, geochemical, mineralogical, and isotopic studies of unweathered drill core confirmed that the sheets are kimberlite (Channer \& Cooper 1997, Channer et al. 1998 Kaminsky et al 1997, 1998b). Kimberlites form a system of layered kimberlite sheets, dipping at low angles to the northeast at $5-20^{\circ}$ (Channer et al. 1998). Eight sheets have been identified, occupying a $10 \mathrm{~km}$ long by $5 \mathrm{~km}$ wide zone along the Quebrada Grande River (Fig. 2). Their thickness varies from 0.1-3.7 m, with an average of $1.2 \mathrm{~m}$ based on 235 drill hole intersections. Kimberlite sheets have been dated at $708 \pm$ $27 \mathrm{Ma}$ (phlogopite, Rb/Sr; Moser 1996) and $711 \pm 5 \mathrm{Ma}$ (phlogopite, Rb/Sr; Kaminsky et al 1997), giving an average of $710 \mathrm{Ma}$ and making the kimberlites the youngest igneous rocks in the area (Channer et al. 1998), apart from diabase dikes of probable Mesozoic age. An age of $840 \pm 10 \mathrm{Ma}$ was obtained by laser $\mathrm{Ar} / \mathrm{Ar}$ analysis of single phlogopite grains (York 1996). The difference between the $\mathrm{Ar} / \mathrm{Ar}$ age and the $\mathrm{Rb} / \mathrm{Sr}$ ages has not been explained since the Ar/Ar release did not show evidence for significant excess Argon. Moser (1996) also found titanite grains in the kimberlite heavy mineral concentrate. Analysis of 10 titanite grains gave a U/Pb age of $1864 \pm 4 \mathrm{Ma}$. These grains were interpreted as xenocrysts from crustal material included in the sheet.

Our studies indicate a kimberlite resource of $45 \mathrm{Mt}$. Diamonds have been found in all the sheets with an average grade of $1.5 \mathrm{cts} / \mathrm{t}$, based on processing of 2857 tonnes of weathered kimberlite from different sheets. According to analysis of local production data and sales records, the average diamond value is about US\$ 50 to $60 / \mathrm{ct}$. Initially, the Guaniamo diamonds were described by Svisero \& Baptista (1973), Nixon et al. (1992), and Meyer \& McCallum (1993). More recent studies by Sobolev et al. (1998) and Kaminsky et al. $(1998 \mathrm{a}, 2000)$ have shown that Guaniamo contains a very high proportion of eclogitic diamonds $(>86 \%$, based on mineral inclusions in diamond).

Kimberlite sheets are well known from many kimberlite provinces (see review by Hawthorne 1968), but have recently gained a higher profile due to several examples which contain 


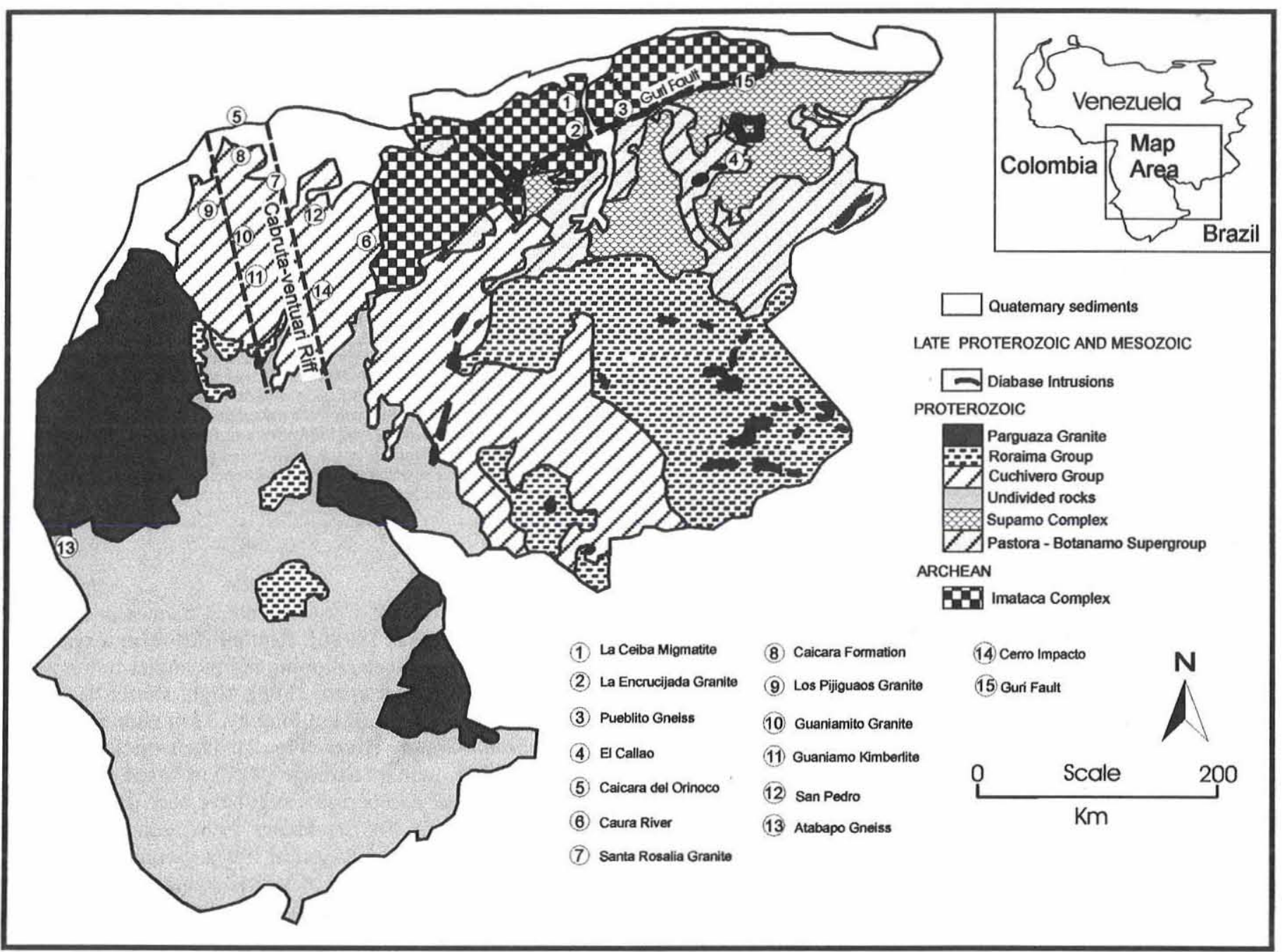

Figure 1 - Geology of the Venezuelan portion of the Guyana shield (after Sidder \& Mendoza 1995), showing the main lithotectonic provinces including: Imataca, Pastora and Supamo, Cuchivero, Roraima, and Amazonas. Rocks of the Amazonas region are shown as undivided. The map area is bounded to the north - west and north by the Orinoco River:

large resources and high diamond grade (e.g., Guaniamo, Venezuela; Snap Lake, Canada-21.3 Mt@1.75 cpt, US\$ 118 $/ \mathrm{ct})$. The remote and jungle covered regions of the Guayana shield are a challenging exploration environment and, relatively speaking, have been poorly explored for kimberlites, especially in the Venezuelan section. It is important that Guaniamo, a new diamond deposit type (multi - level kimberlite sheets) and the only kimberlite so far discovered in the Guayana shield, is well described and understood. Guaniamo Mining Company has conducted regional exploration in the Guaniamo region and has recovered diamond and kimberlite indicator minerals in areas sufficiently separated from the kimberlite sheets to be sure that they are derived from independent kimberlite bodies. This indicates that there are other kimberlites around Guaniamo, and that the diamondiferous kimberlite province is much larger than the immediate area of the Quebrada Grande valley.

The principal objective of this paper is to describe the geological and structural setting and characteristics of the
Guaniamo kimberlite sheets. We also compare these with other kimberlite sheets (e.g., Greenland - Andrews \& Emeleus 1975) and diabase sheets (e.g., Howard 1991) and suggest a probable mode of emplacement and locations of feeder dikes.

REGIONAL GEOLOGY The Venezuelan section of the Guayana shield includes $\sim 25 \%$ of the total shield area, which extends into Brazil, Colombia, Guyana, Suriname, and French Guyana (Gibbs \& Barron 1993). In the north and west, the shield is bordered by Phanerozoic fold belts, the Eastern Cordillera of the Colombian Andes and the Venezuelan Coastal Cordillera. In the south, it is separated from the Central Brazilian Shield by a rift centred along the Amazon River. To the east, the Guayana Shield is now bordered by the Atlantic Ocean, though in the past (specifically, in the Cretaceous) it was connected with West Africa, and its structures were continuous with those of the West African craton. In Venezuela the shield can be divided into four lithotectonic provinces: Imataca, Pastora, Cuchivero, and 


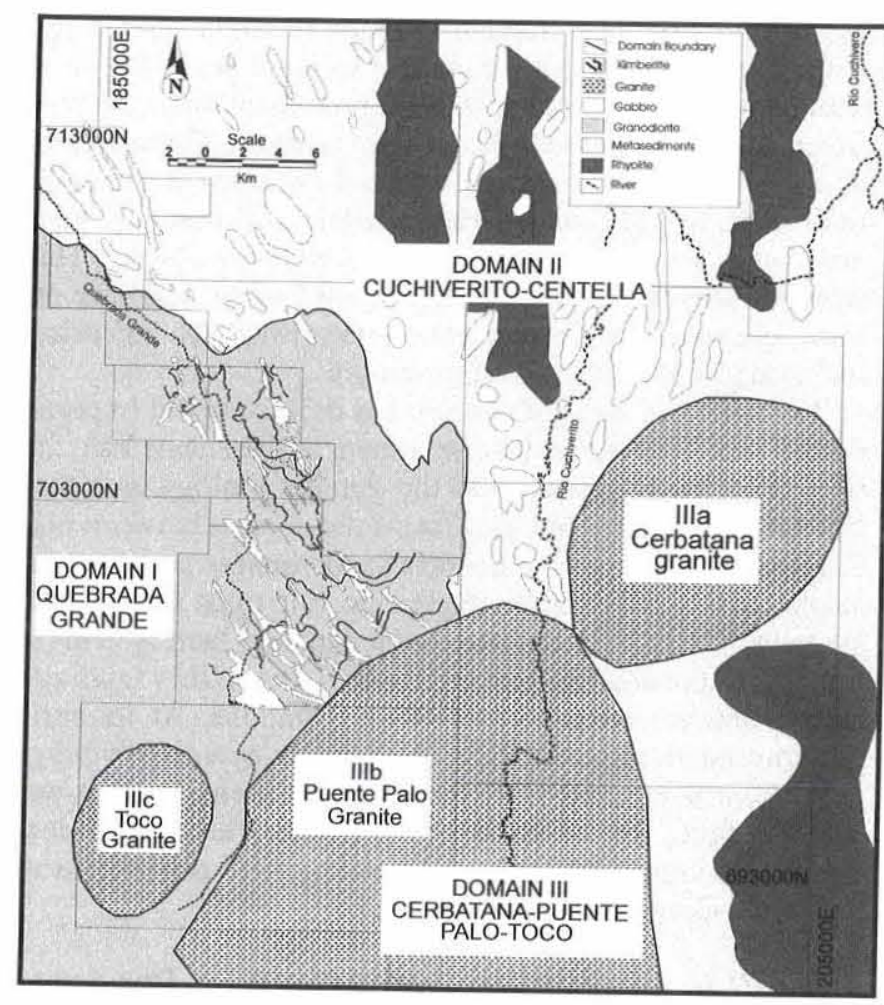

Figure 2 - Geology and Lithotectonic Domains of the Guaniamo Region. Boxed areas represent mineral concessions in Guaniamo.

Roraima (Menéndez 1968, Martin-Bellizia 1972, Gibbs \& Barron 1993). The Amazonas territory forms a fifth region, not yet identified as a separate province. Comprehensive descriptions of the geology of the Venezuelan section of the Guayana shield are to be found in Gibbs \& Barron $(1983,1993)$ and Sidder \& Mendoza (1995). A recent review may be found in Channer \& Anderson (2000). The Guaniamo region is located within the Cuchivero province in the north western part of the Guayana Shield (Fig. 1). The general geological sequence of events in the Guaniamo portion of the shield is summarized in Table 1.

Cuchivero Province This province occurs in the west and south of Bolivar State and consists of extrusive and intrusive felsic rocks. Rocks of the Cuchivero group occur in a zone from Santa Elena, through northern Brazil, northern Amazonas territory, and western Bolívar State over to the Caura river (Fig. 1). Lithologically the group consists of rhyolites, dacites, tuffs, high level granitic porphyries, granites, and lesser quantities of mafic rocks (Rios 1969, Mendoza 1972). In western Bolívar State the volcanic sequence has been denominated the Caicara formation and the intrusive units are known as the Guaniamito granite $(1700+/-80 \mathrm{Ma}, \mathrm{K} / \mathrm{Ar}$, Olmeta 1968) the Santa Rosalia granite $(1880+/-88 \mathrm{Ma}, \mathrm{Rb} /$ $\mathrm{Sr}$, Gaudette et al. 1978), and the San Pedro granite (Mendoza 1972). The volcanic rocks are intruded by the granites, suggesting that they are the oldest exposed units in the group. Volcanic rocks are not regionally metamorphosed or deformed and show a primary vertical flow foliation oriented predominantly on $050^{\circ}$ to $060^{\circ}$. Later faulting has resulted in the development of two structural trends, oriented on $320^{\circ}$ and $020^{\circ}$, with sub-vertical dips (Mendoza 1972). Granitic rocks have also developed these structural foliation trends.

Rocks of the Cuchivero group extend east to the Suapure River, where they come into contact with the Suapure group. The Suapure group (Mendoza 1975) is younger and consists of granite intrusions, the Pijiguao granite and the Parguaza rapakivi granite (1545 +/- $20 \mathrm{Ma}, \mathrm{U} / \mathrm{Pb}$, Gaudette et al 1978). Discordantly overlying the Parguaza granite are stratified sediments of the Roraima group. However, Sidder \& Mendoza (1995) report that conformable contacts between the Caicara formation and overlying Roraima sediments have been observed in southern areas. Hence, Roraima sediments in this region could cover a period from c. $1700 \mathrm{Ma}$ to c. $1500 \mathrm{Ma}$.

Abundant gabbro dikes occur within the Cuchivero province (Rios 1969). They intrude the Santa Rosalia and Guaniamito granites and the volcanic rocks of the Caicara formation, but do not cut Suapure group granites. These are probably part of the Avanavero suite ( 1650 Ma) (Table 1), although mafic dikes were intruded repeatedly throughout the late Proterozoic and Phanerozoic (Gibbs \& Barron 1993).

A large carbonatite intrusion of unknown age, known as Cerro Impacto (see Fig. 1), is located about $80 \mathrm{~km}$ south - east of Guaniamo, and is intruded into rocks of the Cuchivero group.

Tectonic Environment The northern part of the Cuchivero province is bounded to the east by the Río Caura and to the west by the Orinoco river (Fig. 1), both of these following ancient suture zones joining the Cuchivero province to other provinces in the Guayana shield. Sidder \& Mendoza (1995), noting the lack of regional metamorphism and deformation in the Cuchivero group, define this group as post-orogenic and post-Transamazonian. Geochemical data for the Cuchivero group rocks suggests some crustal input to magmas and discrimination diagrams indicate that the granites are transitional from within plate to volcanic arc. Tassinari \& Macambira (1999) include the Cuchivero province within the Ventuari - Tapajós (VTP) geochronological province and also conclude that this province had some crustal input, although the vast majority consists of new, juvenile continental crust which was accreted to older blocks to the east by magmatic ares related to subduction processes. The limited regional gravity data indicate thick crust and a downwarped asthenosphere in the Cuchivero - Guaniamo region (N. Paterson, pers. comm.). So far, no Archean component to the sub - lithospheric continental mantle has been determined for the Cuchivero province.

Various workers (e.g., Martin-Bellizia 1972, Añez 1985) have identified a north - west south - east trending rift valley, the Cabruta - Ventuari rift (see Fig. 1), along which repeated mafic (e.g., gabbro), ultramafic (e.g., Guaniamo kimberlite, lamprophyre), and alkaline (e.g., Cerro Impacto carbonatite) magmatism has occurred. Gaudette et al. (1978) suggested that extensive systems of horsts and grabens formed between 1500 $\mathrm{Ma}$ and $1600 \mathrm{Ma}$ in response to shield scale extension. Associated with this extension was intensive mafic magmatic activity, with extreme fractionation giving rise to intrusions such as the Parguaza granite (Mendoza 1975). In further development of this hypothesis, Gaudette \& Olszewski (1985a,b) and Gibbs \& Barron (1993) have suggested that a subduction zone lay along the position of the present Orinoco river at the border with Colombia, and that the tectonic and magmatic activity was linked to subduction - related processes 
at c. 1.5 to $1.6 \mathrm{Ga}$.

LOCAL GEOLOGY AND STRUCTURE Geology of the Guaniamo area The Guaniamo kimberlite sheets are located $\sim 150 \mathrm{~km}$ south of Caicara del Orinoco (Fig. 1). The geology of Guaniamo (Diaz 1977, Channer \& Cooper 1997) in general consists of an eastern area dominated by extrusive felsic rocks of the Caicara formation (Fig. 2 and Table 1), a western area dominated by variably foliated granodioritic rocks, and a southern area composed of massive, coarse grained granite intrusions, dated at $1425+/-14 \mathrm{Ma}$ by single zircon U/Pb analysis (Channer et al. 1998, Moser 1996). Gabbro intrusions are abundant throughout the region as dikes, sheets, and plugs, and are probably about $1650 \mathrm{Ma}$ in age. Syenite intrusions formed around $1400 \mathrm{Ma}$ and occur in the west of the area.

Lithotectonic domains in the Guaniamo area Through interpretation of geological, geophysical, geomorphological and structural data, the Guaniamo region can be divided into three lithotectonic domains (Fig. 2). Sources of data include Landsat satellite images, airborne radar, aeromagnetic, and aeroradiometric maps, geological and topographical maps and aerial photographs. The region is characterized by a high overall fracture density, with north-west, north-east, and north trends being most notable (see Fig. 3). There are some areas where higher numbers of intersections occur, especially at either end of the main Guaniamo section of the Puente Palo fault, at boundaries between lithotectonic domains I, II, and III.

DOMAIN I: QUEBRADA GRANDE This domain covers the western part of Guaniamo (Fig. 2) and consists predominantly of granodiorite and quartz diorite. It is limited to the south by contacts with younger granites and to the east with rocks of the Caicara formation. This domain is dominated by a north to north-west structural trend, expressed in faults and fractures (Fig. 3), in the topography, and in foliated granodiorite and abundant gabbro dikes, which form prominent magnetic highs. Steep scarps along the sides of the Quebrada Grande valley, and also along higher valleys, reflect these north-west trending fault lines. In addition, a series of north-west trending, gently north-east dipping fractures is also well developed. These fractures show a regional easterly dip of 5 to $20^{\circ}$ and have only been observed in association with ultramafic intrusions, including kimberlite and lamprophyre.

The southern limit of domain I is defined by an important north - east trending fault zone, known as the Puente Palo fault (Fig. 3). This is reflected in the geomorphology as a steep sided, linear valley, and also forms the contact between older Cuchivero group rocks to the north and younger granites to the south. On a regional scale, the Puente Palo trend can be traced out to the Caura river and across it to the Guri fault system (see Fig. 1). Exposures of volcaniclastic rocks in this fault zone exhibit intense north-east oriented foliations. At its northeastern end the Puente Palo trend abuts against a younger granite intrusion and is displaced south along a north-west trending fault. To the north of the Puente Palo fault at least three other important north-east trending fault zones cross the Quebrada Grande corridor.

DOMAIN II: CUCHIVERITO-CENTELLA This domain consists of tuffs and coarse grained pyroclastic rocks. Associated intrusive rocks include granodiorite, quartz diorite, and quartz syenite, mostly as dykes. Fault - bounded regions of dark green rocks of possible dacitic composition, also occur. Faults are oriented north - west $\left(330^{\circ}-340^{\circ}\right)$, accompanied by gabbro and granodiorite dikes, and north - east $\left(040^{\circ}-050^{\circ}\right)$, accompanied by diabase dikes which are possibly of younger age than the gabbro. Discrete, north-east trending zones of shearing, often occupied by deformed quartz veins, occur

Table I - Geological and structural evolution of the Guaniamo Region.

\begin{tabular}{|c|c|c|}
\hline Age (Ma) & Event & Structure \\
\hline Quaternary & Alluvium - including several levels of terraces & Brittle fault activity \\
\hline Tertiary & Probable first exposure of kimberlites & Uplift, tilting, erosion \\
\hline c. 200 & Diabase dikes - tholeiitic & North-west and Easterly orientations \\
\hline $500-600$ & UNNAMED & $\begin{array}{c}\text { Thermal event registered in isotopic systems across } \\
\text { the region }\end{array}$ \\
\hline 710 & Kimberlite sheets & $\begin{array}{l}\text { No penetrative deformation but slightly affected by } \\
\text { faulting }\end{array}$ \\
\hline 850 & Lamprophyre dikes & Slightly affected by faulting \\
\hline$? 1200$ & NICKERIE OROGENY & Reactivation of north-east trending faults \\
\hline c. 1400 & Toco Syenite and mica veins & Contains gneissic zones \\
\hline 1425 & Puente Palo granite & $\begin{array}{l}\text { Late pegmatites cut foliated rocks in the Puente } \\
\text { Palo fault zone }\end{array}$ \\
\hline $1450 ?$ & NICKERIE OROGENY & $\begin{array}{l}\text { Ductile deformation along north-east trending } \\
\text { faults }\end{array}$ \\
\hline $1700-1500$ & $\begin{array}{c}\text { Roraima Group - fluvio - deltaic and lacustrine } \\
\text { sediments; age of deposition decreases from } \\
\text { east to west }\end{array}$ & $\begin{array}{l}\text { Dips mostly }<20^{\prime \prime} \text {; local high dip due to faults (e.g., } \\
\text { Pass of Guanay - fault related folds give local } 80^{\circ} \\
\text { dips). Open folds in lower part of sequence. }\end{array}$ \\
\hline c. 1650 & $\begin{array}{l}\text { Avanavero Suite - continental tholeitic gabbro } \\
\text { dikes, sills, inclined sheets and plugs }\end{array}$ & $\begin{array}{c}\text { Crustal extension in areas of high dike frequency } \\
\text { such as the Quebrada Grande valley, within the } \\
\text { Cabruta - Ventuari rift zone }\end{array}$ \\
\hline$? 1700$ & $\begin{array}{c}\text { Cuchivero Group - associated granitic rocks } \\
\text { (Guaniamito, San Pedro, and Santa Rosalia } \\
\text { granites) }\end{array}$ & Foliated in discrete zones with north - west and \\
\hline $1930 ?$ & $\begin{array}{l}\text { Cuchivero group (Caicara formation): felsic to } \\
\text { intermediate, mostly subaerial, volcanics and } \\
\text { tuffs }\end{array}$ & north - east orientations \\
\hline
\end{tabular}


throughout the volcanic rocks. Most of the domain forms a low relief etch plain, covered by savanna - type vegetation. The western edge of this zone trends predominantly north-west, coincident with the eastern side of domain I. The southern limit of domain II is defined predominantly by the contact with the Cerbatana granite, which forms a high massif.

DOMAIN III: CERBATANA-PUENTE PALO-TOCO This domain encompasses the southern part of Guaniamo. Geologically it is characterized by three large, massive granite intrusions separated by narrow zones of country rocks. These granites are highly distinctive on geophysical maps. The Cerbatana granite is a zoned intrusive with a more magnetic and mafic northern and eastern rim, as compared with the center. The center is more potassic than the rim. It lies immediately north of the offset extension of the Puente Palo fault. The Toco granite is radiometrically distinctive and does not appear to be crossed by any significant faults. The granites form hilly topography and drainage networks follow well developed joint systems. Within $2 \mathrm{~km}$ of the northern contact with the Puente Palo fault, larger drainages follow north-east and north-west trends, reflecting the presence of underlying laults. Granite emplacement was after ductile deformation on north-east trending faults (granites are massive, pegmatite dikes cut the Puente Palo fault) but the granites have been affected by subsequent brittle faulting along the same structures. Occasional diabase dikes have been mapped within the granites, confirming that some mafic dikes are younger than $1425 \mathrm{Ma}$.

GEOLOGY OF KIMBERLITE SHEETS Morphological expression in the Landscape Kimberlite outcrops and subcrops occur both in valleys and hill slopes (see Fig. 4)

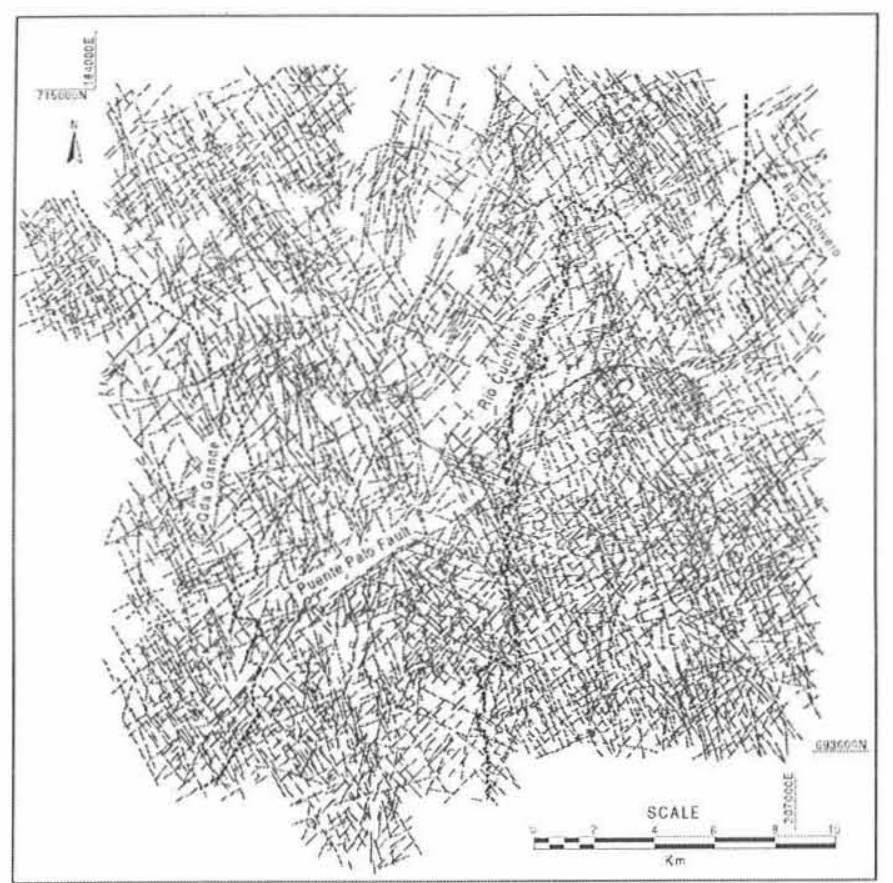

Figure 3 - Fracture map of the Guaniamo region, derived from analysis of 1:20,000 scale air photographs and exert a strong local influence on local landscape morphology. Some hill slopes (e.g., Bicicleta and Desengaño east slopes, Comisario south slope) are dip slopes with the kimberlite either at or close to the slope. The Candado valley is particularly wide due to the coincidence of the erosion surface with the sub - horizontal fractures containing the kimberlite sheets. Formation of large granite boulder areas on the west side of Candado valley may have been aided by collapse along joints above shallow, weathered kimberlite. Exposed shallow dipping granite pavements on hill slopes in some cases represent the footwall remaining after kimberlite has been removed by erosion (e.g., La Peinilla) and may show curious fracturing patterns related to original kimberlite emplacement. Natural kimberlite outcrops are rare, occurring only where lateritization has occurred. Lateritized kimberlite forms discontinuous sheets on flat or gently inclined slopes at higher elevations. The laterite has now been mostly removed by local diggers, but in its undisturbed state is covered by a few meters of soil (e.g. La Lapa). Down dip from lateritized kimberlite there occurs a mottled, nodular soil where laterite fragments are contained in a red-brown soil. In the upper part of the soil profile, exposures of other, unlateritized, kimberlites form a dark red, massive, featureless soil which, taken in isolation, is difficult to recognize as kimberlite. In Guaniamo soil profiles typically range from 5 to $40 \mathrm{~m}$ in depth and the intense tropical weathering has had drastic effects on rock appearance.

Composition and Texture Guaniamo kimberlites are variable grain size (fine to coarse) porphyritic rocks with 20 to $70 \%$ olivine megacrysts and phenocrysts. The extreme cases are essentially aphyric kimberlite (observed in the Los Indios sheet) and olivine cumulates. Usually, such coarse porphyritic kimberlites are in the lower parts of the sheets. Because of a large amount of mica (particularly in the groundmass) they may be classified as micaceous. All the sheets contain host rock xenoliths (predominantly granodiorite, diorite, and gabbro) and, very rarely, mantle garnet peridotite. Accessory minerals are represented by strongly kelyphitized pyrope garnet, chrome spinel, chrome-diopside and rare ilmenite with 0.16-1 wt.\% (rarely up to $6 \mathrm{wt} . \%$ ) MgO. From their chemical and isotopic characteristics the kimberlites are similar to transitional kimberlites (Skinner et al. 1991) and Al - series kimberlites from the Arkhangelsk region in Russia (Kaminsky et al. 1998b). They also show isotopic similarities to Brazilian kimberlites (Bizzi et al. 1991). Kimberlites are commonly overprinted by secondary alteration products, resulting principally from serpentinization of olivine, carbonatization, phlogopitization, and chloritization. Such alteration is observed even in deep drill holes.

Almost all of the kimberlite outcrops in the saprolite zone have been created by local diggers (Fig. 5a, 5b, 5c). These outcrops are ephemeral, lasting only as long as the pit is open. In the saprolite layer the kimberlite shows full textural preservation. Different phases or layers of kimberlite are distinguished both by texture and by color. The saprolitic kimberlite produces a wide range of weathering colors, for which it is known locally as 'pintura' (Spanish for 'paint'). It is mostly clay-dominated but occasionally there are very hard, siliceous layers caused by low temperature silicification. Associated with the silicification there may be small veinlets of opaline silica. Textures are perfectly preserved within the silicified layers. 


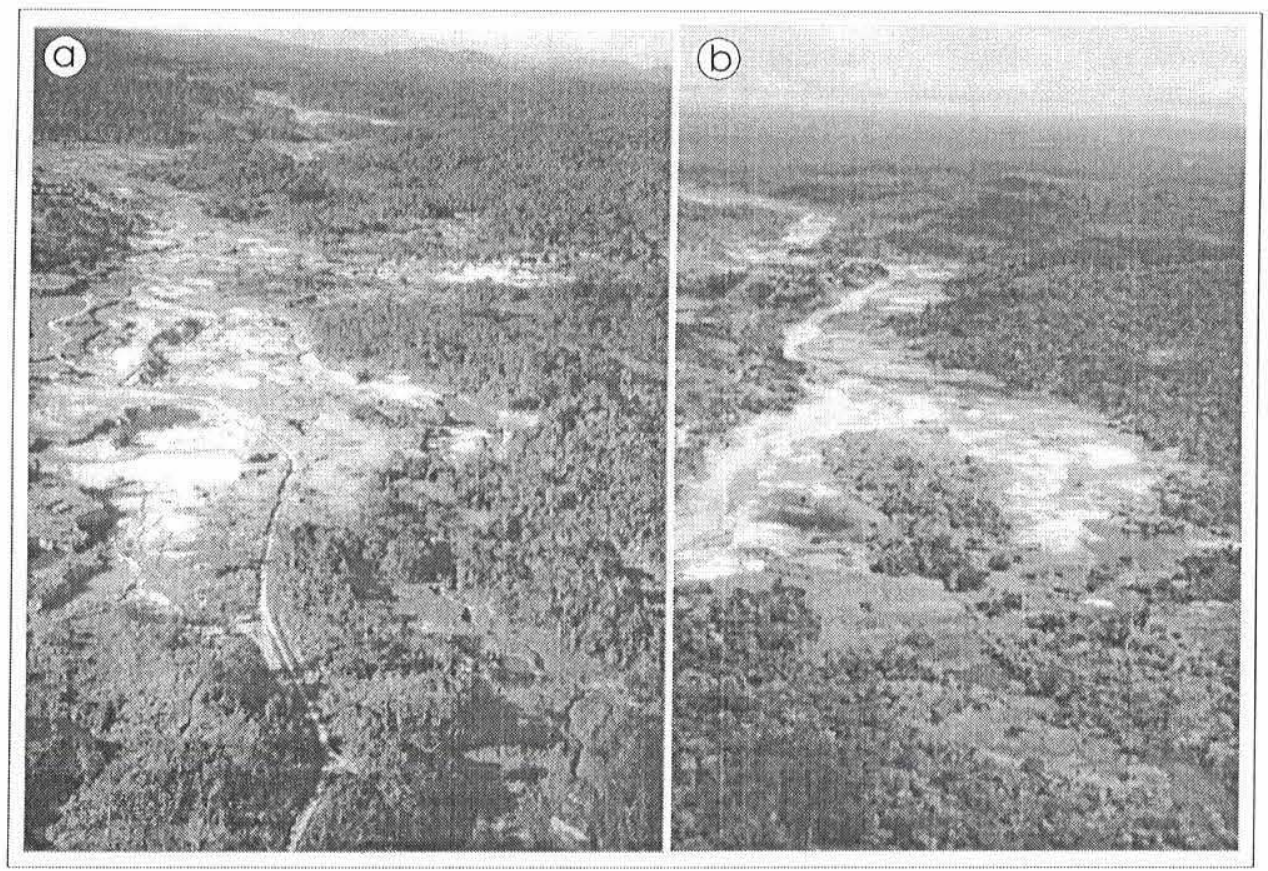

Figure 4 - Landscape in the area occupied by kimberlite sheets. a) View to the north along the Quebrada Grande valley, showing alluvial workings at center and left. The La Ceniza kimberlite sheet dips to the east, beneath the road and beneath the forested ground at right. The Nueva Bulla and Desengaño sheets occur on the ridge just off the right side of the photo, b) View to north over the town of Milagro in the Quebrada Grande valley. The Los Indios - La Peinilla kimberlite sheet follows the ridge on the east side of the valley. The Desayuno and Bicicleta sheets occur in the top left of the photo, left of the river and left of the sharp kink in the river course. This kink is related to the Milagro north-east trending fault zone.

The following textural varieties of kimberlite may be distinguished:

1. Massive, fine-grained kimberlite (Figs. 5a, 5b). In the weathered zone, this kimberlite type forms clay, which may be one of many colors including red, black, gray, green, yellow, brown, blue, and white. Clay pseudomorphed olivine phenocrysts and xenocrysts may be observed and also occasional phlogopite crystals. Layers distinguished by different colors may also contain different proportions of olivine crystals.

2. Coarse, porphyritic, macrocrystic kimberlite (Fig. 5c). In the weathered zone, coarse olivine xenocrysts are replaced with clay minerals. In areas of strong weathering, such as in laterites, the preservation of this texture is one of the most useful aids in identifying kimberlite. This variety commonly contains coarse kelyphitic pyrope garnet xenocrysts in a fine-grained, olivine-phlogopite matrix

3. Olivine-rich, cumulative, coarse-grained kimberlite (Fig. 5c). Olivine megacrysts are preferentially aligned with their long axes perpendicular to the intrusion margin. They work as obstacles within the magma pathway, causing a grouping of olivine megacrysts, which eventually build up to a total blockage, allowing only a slow seepage of magma to pass.

4. Xenolith-rich kimberlite breccia. Xenoliths are from local rock types and of variable size (up to $0.5 \mathrm{~m}$ ) and shape (both elongate and rounded). In some cases the xenoliths form patterns, with long, linear xenoliths oriented parallel to the wall rock contact, separating zones of rounded xenoliths. Xenoliths often have alteration rims, which weather to different colors. In some places the kimberlite may split to enclose meter-scale pieces of wall rock. Sometimes the xenolith texture suggests explosive brecciation (e.g., Resbalon, 024, see Fig. 5d) and in other places forceful fracturing (e.g., Candado, Desengaño, sec Fig. 5e). In rare cases (e.g., Desengaño, see Fig. 5f) imbrication of xenoliths gives an indication of magma flow direction (east to west in this case). Xenoliths are stacked like tiles, with their long axes dipping towards the source of magma flow. This type of relationship between imbrication and magma flow direction was confirmed by Knight \& Walker (1988), using magnetic fabric analysis of diabase dykes in Oahu.

The textural varieties of kimberlite are the result of the uneven extent of hydrodynamic sorting of olivine grains and gravity induced differentiation of megacrystic olivine grains during transportation and solidification. The emplacement of different melt portions resulted in the formation of a layered series of well sorted rocks, from fine to coarse porphyritic kimberlites or, in effect, olivine cumulates. For example, in the Desayuno kimberlite sheet (Fig. 6) two layers of kimberlite were observed. The bottom of the lower layer consists of coarse olivine macrocrystic kimberlite. This is overlain by porphyritic kimberlite and kimberlite breccia. The two layers are separated by a sheared zone containing granite lenses. In the hanging wall, there are numerous small $(1-5 \mathrm{~cm}$ thick) kimberlite 
veinlets, forming a contact zone up to $5 \mathrm{~m}$ thick. Sampling of hanging wall kimberlite veinlets in Guaniamo has shown that they are diamondiferous.

Structural Characteristics of Kimberlite Sheets Kimberlite sheets were mapped based on pits and excavations made by artisanal miners, on auger and diamond drill holes, and on diamond indicator mineral occurrences in streams along strike from kimberlite intersections. Fractures were identified from topography (i.e., slope changes), and rectilinear stream patterns. Faults have been mapped from 1:10,000 scale black and white air photos taken in 1999. Additional sources of data include: black and white air photos $(1: 10,000,1999)$, topography derived from same air photos $(1: 5,000,1999)$, field observations, drill data, aeromagnetic maps (1:20,000, 1994), ground magnetic maps $(1: 5,000)$, and previous geological observations. The structure and geology in the area of the kimberlite sheets are shown in Figure 7.

Kimberlites occur in the Quebrada Grande valley (see Fig. 4a) and in the uplands and higher valleys in the surrounding area (Fig. 4b), predominantly within domain I. Recently, kim- berlite veins were discovered north of the kimberlite sheets, just inside domain II (see Fig. 2). Strike directions are principally north-west with a subsidiary north-east direction. Regional dips are to the east or south - east and range from sub-horizontal to $\sim 20^{\circ}$. The combination of north-west trending topography and north-west striking, shallow dipping sheets results in kimberlite outcrop lines which in general follow topographic contours. There are at least eight kimberlite sheets covering 10 $\mathrm{km}$ of north-westerly strike, and a width of $\sim 5 \mathrm{~km}$. These are: Bicicleta - Desayuno, Los Indios - 024 - La Peinilla Cordero, Hueso Duro-La Ceniza - 039, Nueva Bulla, Bulla de las Mujeres - La Hoya, Desengaño - Candado, and El Tigre land 2 (Fig. 7). Kimberlite at deeper levels in Bicicleta represents another possible sheet of as yet unknown size. Kimberlite has been found at elevations ranging from $145 \mathrm{~m}$ a.s.l (above sea level) in Bicicleta to $410 \mathrm{~m}$ a.s.l in Desengaño, giving a minimum vertical range of $265 \mathrm{~m}$. Adjusting for dip and including sheets which are structurally higher than Desengaño (e.g., Los Indios, El Tigre), we estimate that the known kimberlite sheets cover a vertical range of 400 to 500 $\mathrm{m}$. Adjacent sheets are separated by $50-125 \mathrm{~m}$ (perpendicular

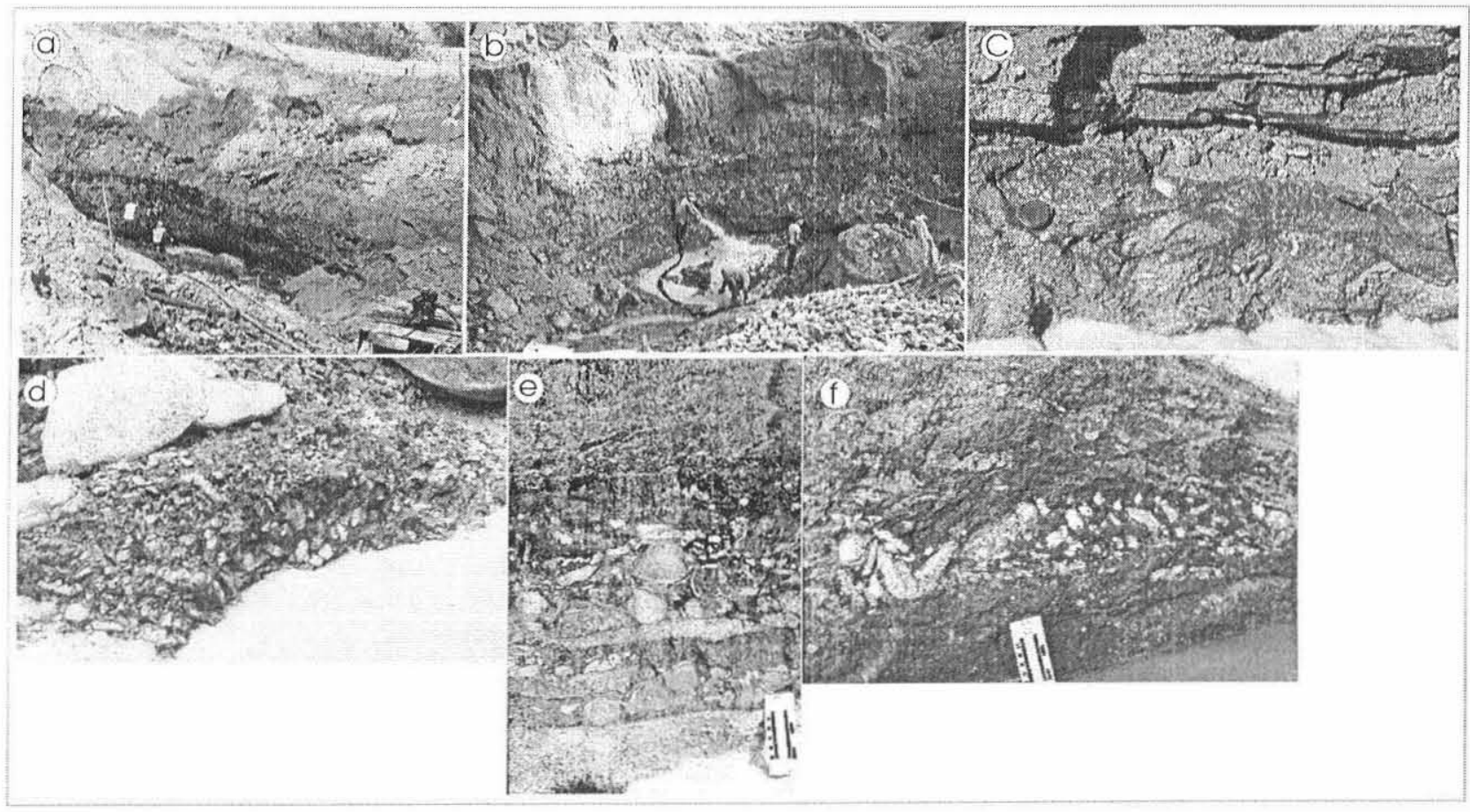

Figure 5 - Outcrops of weathered, saprolitic kimberlite. a) La Ceniza: kimberlite is the massive, dark layer dipping into the bank. It is overlain by granodiorite and tailings. The two men are standing on the footwall. b) La Ceniza: the upper contact of the kimberlite sheet is about $1 \mathrm{~m}$ above the head of the man with the hose. Xenoliths of local rock, both rounded and elongate, are visible as lighter patches within the kimberlite. The xenoliths are well separated. The elongate screens are parallel to the wall rock contacts. The men are standing on the footwall and the kimberlite is overlain by granodiorite. c) La Ceniza: close - up of upper part of kimberlite sheet showing sharp contact with granodiorite and contact parallel fractures in the hanging wall. Dark, massive kimberlite contains rare xenoliths and has irregular contact with an underlying layer of coarse, macrocrystic kimberlite. d) Resbalón: kimberlite breccia with randomly oriented, light colored fragments. e) Desengaño: the lower kimberlite contact is just below the top of the scale card. The bulk of the kimberlite sheet in this exposure contains mumerous granodiorite xenoliths, both rounded and elongate. Note the white, small imbricated xenoliths at center left. Just above these xenoliths, the kimberlite becomes more massive over about $15 \mathrm{~cm}$, before the hanging wall contact. Note that kimberlite alteration veins occur in both the hanging wall and the footwall. f) Candado: elongate, curved zone of xenolith - bearing kimberlite surrounded by dark, massive kimberlite. here the lower contact is not visible. The white xenoliths show imbrication, suggesting magma flow from right to left, which in this case is east to west. The upper contact with granodiorite is irregular: 


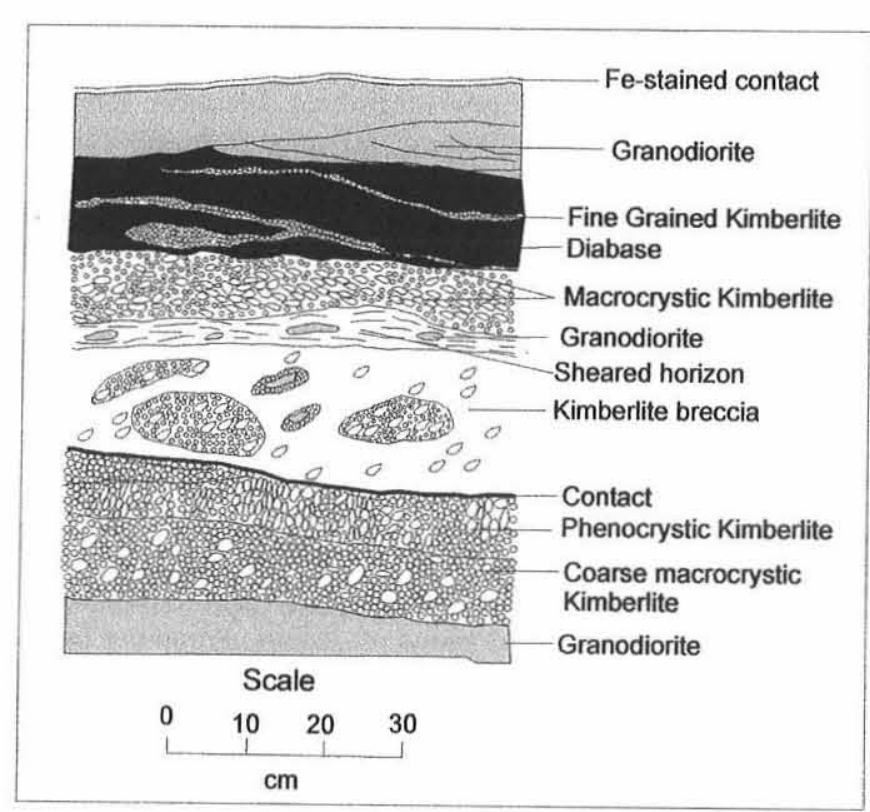

Figure 6 - Detailed profile through the Desayuno kimberlite sheet, showing different types of kimberlite textures. At this locality, kimberlite - related veins were observed up to $5 \mathrm{~m}$ above the hanging wall contact. This figure shows only the immediate contact area. This exposure shows four types of kimberlite: coarse macrocrystic, phenocrystic, fine grained, and breccia.

to dip). The maximum down dip extent proven by drilling for a single sheet is $1 \mathrm{~km}$ for La Ceniza, but the final extent of the this sheet is unknown. Kimberlite sheets pass without break from granodiorite to gabbro, occasionally changing in orientation upon crossing the contact. In general, footwall surfaces show local topographical variation in the order of 5 to $25 \mathrm{~m}$. In some places kimberlite veins splay off from the kimberlite sheet at high dip angles. These veins are thin $(<10$ $\mathrm{cm}$ ) and are unlikely to extend far from the main kimberlite sheet. No veins or dikes have been observed which connect one kimberlite sheet to the next sheet, some 50 to $125 \mathrm{~m}$ above or below. However, in numerous boreholes zones of kimberlite veins have been found at depths well separated from the main kimberlite sheet, sometimes above (e.g., La Ceniza) and sometimes below (e.g., Bicicleta).

The thickness of the kimberlite sheets varies from $3.7 \mathrm{~m}$ down to $10 \mathrm{~cm}$ and may change rapidly over $10 \mathrm{~m}$. Analysis of drill data shows that there is no significant difference between the range and mean thickness of weathered saprolitic kimberlite (mean $1.02 \mathrm{~m}$, s.d. $0.81 \mathrm{~m}, \mathrm{n}=91$ ) compared with fresh kimberlite (mean $0.91 \mathrm{~m}$, s.d. $0.82 \mathrm{~m}, \mathrm{n}=96$ ). This is consistent with the observation that primary kimberlite textures are preserved in the saprolite, i.e., no significant volume change has occurred, in contrast to weathered kimberlite at higher levels in the soil profile.

GEOLOGY AND STRUCTURE WITHIN DOMAIN I In the north, and from west to east (see Fig. 7) the sheets are: Bicicleta-Desayuno, La Peinilla-Los Indios-024, El Tigre 1, and El Tigre 2 (see Fig. 8a). In the south, and from west to east the sheets are: Hueso Duro-La Ceniza-039, Nueva Bulla,
Desengaño-Candado, Cordero, and Comisario-La Hoya (see Fig. 8b). Most sheets strike north-west and dip north-east at 5$20^{\circ}$, but those in the extreme south strike north-east and dip south-east. At Comisario dips of $35^{\circ}$ to $60^{\circ}$ to the south-east, into the Puente Palo valley, have been recorded.

The Bicicleta and Desayuno sheets have been defined from outcrops and drill holes. Desayuno has been described over a limited area and has a complicated geometry with abundant veins in the hanging wall. Drill intersections greater than $2 \mathrm{~m}$ have been obtained. The Desayuno sheet is bowl - shaped, outcropping to the west and south and fingering out to the north. To the east, however, it is open and projects beneath the Quebrada Grande river. In Bicicleta the kimberlite is thin, always less than $1 \mathrm{~m}$, but of very high grade. The Bicicleta sheet outcrops as laterite on a ridge to the west and dips eastwards below the Quebrada Grande. Within the active river valley the kimberlite has been removed by erosion, but it has been exposed in diggers pits on the right bank. Drilling in $\mathrm{Bi}$ cicleta found kimberlite veins between 124 and $128 \mathrm{~m}$ below ground level, some $107 \mathrm{~m}$ below the Bicicleta sheet. Stream sampling on hills to the north - west of Bicicleta has recovered diamond indicator minerals, showing that the sheet continues further north.

La Peinilla occurs in a north - east trending valley cutting the north - west trending ridge on the right side of the Quebrada Grande (see fig. 4b). Both north and south of La Peinilla there are numerous pits and shafts where local diggers have extracted weathered kimberlite. In this area no down dip drilling has been done but the continuous occurrence of miners' pits and shafts, and footwall granite pavements, between the La Peinilla and Resbalón kimberlite showings (locations 8 and 20 in Fig. 7), implies continuity of the kimberlite sheet between these sites. La Peinilla forms the northward extension of the Los Indios sheet, which is the most extensively studied in terms of drilling and sampling. Through more than 200 drill holes the kimberlite sheet has been followed over more than $2 \mathrm{~km}$ along strike in the Los Indios 024 area. Thicknesses in La Peinilla are rarely above $1 \mathrm{~m}$, while Los Indios and 024 have numerous areas with kimberlite more than $2 \mathrm{~m}$ thick. Analysis of diamond size data from La Peinilla, Los Indios, and 024 has confirmed that the diamonds form a single population.

The El Tigre 1 and 2 sheets have so far been little studied. The El Tigre I sheet was exposed at site 19 (see Fig. 7) and abundant positive stream samples and recovery of kimberlite fragments in streams, indicate the continuity of these sheets. Drilling to the south of locality 19 (Fig. 7) passed through the El Tigre I sheet at $13.6 \mathrm{~m}$, and the Los Indios sheet at $81.8 \mathrm{~m}$, showing that the two sheets are vertically separated by $68.2 \mathrm{~m}$. The vertical separation between the projection of the Desayuno sheet and the La Peinilla sheet is $\sim 100 \mathrm{~m}$.

The La Ceniza sheet shows irregular topography along the profile (Fig. 8b), outcropping at the south-west end in the Quebrada Grande valley, and continuing down dip beyond hole 092. Hueso Duro forms the south - west margin of the La Ceniza layer. The La Ceniza sheet outcrops to the north, but on its south side is connected with the 039 kimberlite sheet. In La Ceniza the kimberlite in several places separates into multiple layers and in places has been slightly offset by brittle faulting. In hole 97-092, kimberlite veins were found at various levels above the main layer: The kimberlite at the Nueva Bulla, on the slope between La Ceniza and the higher level Desengaño sheet, 


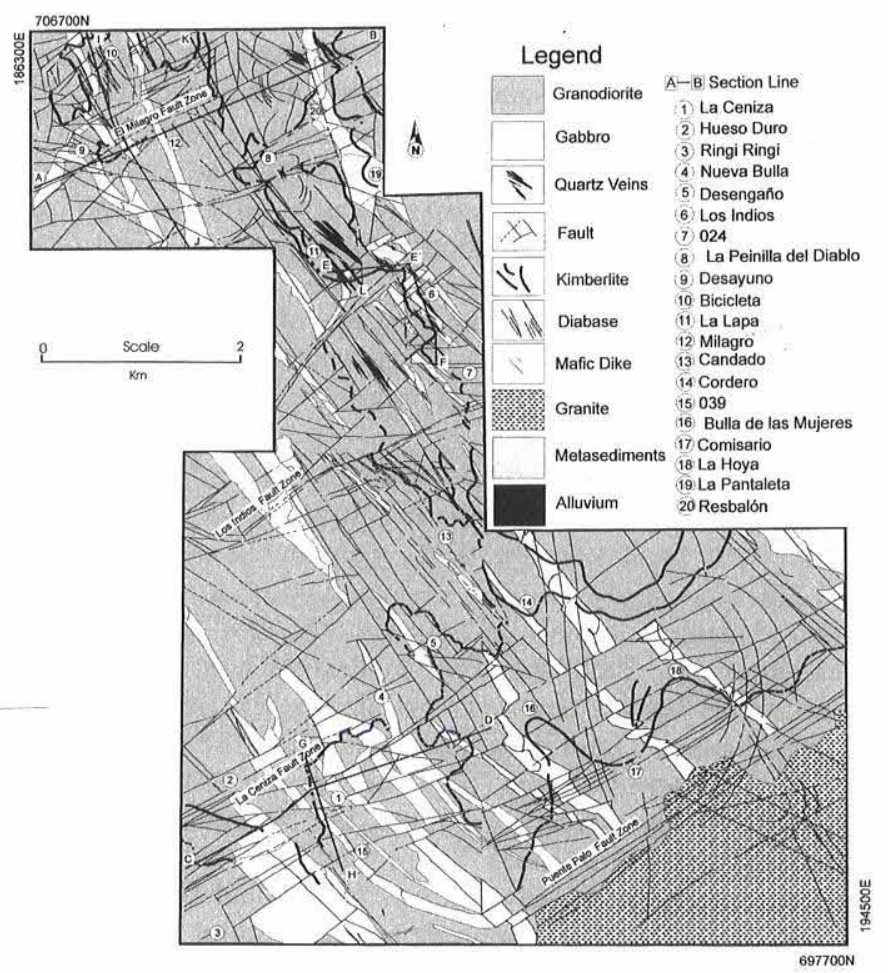

Figure 7 - Structure and geology of the Quebrada Grande basin. Kimberlite localities mentioned in the text are shown by number. Section lines for subsequent figures are also shown. Note that the geological legend in this figure applies also to figures $8,9,13$, and 16 .

might be connected with these veins in hole 92. The La Ceniza sheet has been well defined by drilling and contains areas where the kimberlite is more than $2 \mathrm{~m}$ thick.

To the north-east of La Ceniza, a higher level kimberlite sheet follows the (dip) slope from Desengaño down into Candado valley, where it is mostly mined out, and continues under the ridge on the east side of Candado valley. The Candado valley is anomalously wide and contained exceptionally rich alluvial deposits, now all mined out. This sheet has not yet been drilled down dip on the east side of Candado valley. The Cordero sheet (locality 14 in Fig. 7) is structurally above the Candado sheet and may correlate with the Los Indios - 024 sheet. Diamond indicator minerals have been recovered from streams well above Cordero, showing that another sheet occurs at higher elevation, possibly correlating with the El Tigre I sheet to the north. Kimberlite exposures more than $2 \mathrm{~m}$ thick have been documented in both Candado and Cordero.

The kimberlite sheets in the southern part of the area (i.e., localities 16, 17, and 18 in Fig. 7) are close to the Puente Palo fault zone. Drilling has not been done in these areas and mapping is based on outcrops and stream samples. At Comisario the sheet dips steeply to the south-east into the fault zone and attains a thickness of 1.5 to $2 \mathrm{~m}$. In the up dip direction the kimberlite sheet follows the topography and is intermittently exposed beneath large boulders on the hill slope. Further up dip the sheet changes in orientation and at Bulla de las Mujeres (site 16 in Fig. 7) it strikes north - west and dips north - east.

Aerial photograph and topography interpretation has shown a large quantity of fractures of different directions and dimensions (see Figs. 3 and 7). Some are local, while others form part of regional fault systems. The principal Quebrada Grande north-west trending lineament, about $6 \mathrm{~km}$ wide, consists of at least three main directions of fault groups: $345-$ $335^{\circ}, 320-325^{\circ}$ and $300-310^{\circ}$. Extended zones containing high densities of north-west trending faults (e.g., Desayuno-Bicicleta, Los Indios, Desengaño) separate blocks with relatively low densities of north-west trending faults (e.g., La Ceniza, Candado, La Hoya). Zones with abundant quartz veins are common along the north - west trending faults and the abundant mafic dikes also tend to follow this trend.

The north-west structural trend is complicated by crosscutting north-east trending fault systems. Note that the northeast trending faults, especially the Puente Palo lineament, are better expressed in the aerial photographs than the north-west trending faults. Most probably they have been reactivated both in the Mesozoic (e.g., north-east trending diabase dikes have been observed within these fault zones - see Fig. 7) and recently (e.g., river terraces in north-east trending valleys reflect neotectonic movements). Most gabbro dikes show lateral offsets, up to a maximum of $300 \mathrm{~m}$ : these offsets are most pronounced in the southern part of the area in the La Ceniza and Puente Palo fault zones. Moving in a north-west direction from the Puente Palo fault, there are three additional north-east trending fault zones of high fracture density: La Ceniza, Los Indios and El Milagro. The width of these zones varies from $450 \mathrm{~m}$ (El Milagro fault) to $600 \mathrm{~m}$ (Los Indios fault) and about $1 \mathrm{~km}$ (La Ceniza fault). The size of the lateral displacements across these fault zones increases progressively from about ten meters inside the El Milagro fault to $100-150 \mathrm{~m}$ within the Los Indios fault and more than $500 \mathrm{~m}$ inside of the La Ceniza fault zone.

LOS INDIOS - 024 KIMBERLITE SHEET In Los Indios 024, through a combination of drill and outcrop data, the kimberlite sheet has been shown to be continuous over $2 \mathrm{~km}$ along strike and $500 \mathrm{~m}$ down dip. Additional geological data (outcrops, drill holes, miners' pits, and stream samples) show that this section is part of a much larger sheet, which extends for at least $8 \mathrm{~km}$, with occasional breaks.

In cross-section (see Fig. 9) the Los Indios kimberlite sheet shows a structural low point, around $260 \mathrm{~m}$ a.s.l, in the northern part around hole 145. Away from this point it rises to the north and west, while to the south it undulates, showing additional highs and lows and small possible fault displacements.

A geological model (Fig. 10) was created for a $1200 \mathrm{~m}$ section of the Los Indios sheet using the 'Stratmodel' software package (Mincom Pty Ltd, Australia). The data points used to generate the model are shown on Figure 10; these points are located in the shallower portion of the kimberlite sheet. The Los Indios sheet has a general north-west strike and an overall north-east dip of 6 to $8^{\circ}$, showing regularity over $1 \mathrm{~km}$. Variations occur over distances of $50-100 \mathrm{~m}$, forming structural highs and lows, elongated in a down dip direction. Structural contours in the northern part of the modeled area show two lows, one oriented north and the other east, separated by an easterly trending high. In the southern part of the area there is one south - east trending high adjacent to a similarly oriented low. In both cases the amplitude from high to low is 25 to 30 $\mathrm{m}$. These features are comparable to the undulations observed 
in the line profile shown in Fig. 9. The kimberlite sheet is characterized by variable thickness from $<0.5 \mathrm{~m}$ up to $2.5 \mathrm{~m}$ (see Fig. 11). Zones of relatively consistent thickness occur over at least $300 \mathrm{~m}$. In rare cases variations from 2.5 to $0.5 \mathrm{~m}$ may occur over $\sim 10 \mathrm{~m}$. By comparison with Figure 10, there is a correlation between easterly trending zones of low thickness, and the structural highs shown by the footwall contours in Fig. 10. Zones of thicker kimberlite coincide with structural lows but spread out beyond them.

Structural contour maps were also generated over small areas $(200 \mathrm{~m}$ by $150 \mathrm{~m})$, which were worked by local diggers who opened shafts down through the overburden to the weathered kimberlite. At the La Peinilla 'bulla' (Fig. 12) the kimberlite footwall undulates on a horizontal $40 \mathrm{~m}$ scale, over a topographic range of 5 to $8 \mathrm{~m}$. The general strike direction is north - west and the dip is to the north - east. In this small area there are two principal north - east trending lows, separated by a central high. Within the two lows there are smaller highs. Thickness contours are also shown in Fig. 12 and tend to be parallel to dip, with values that undulate along strike from 0.3 to $1.1 \mathrm{~m}$ (Fig. 12). The distance along strike from maximum to minimum thickness is $\sim 50 \mathrm{~m}$. The area of thin kimberlite (less than $0.5 \mathrm{~m}$ ) correlates well with the central high, while the thicker kimberlite occurs in the area of the structural lows, but also overlapping with adjacent highs. This relation between kimberlite thickness and topography on the kimberlite sheet is the same as observed for Los Indios (see Figs. 10 and 11).

LA CENIZA KIMBERLITE SHEET In La Ceniza a strike length of $2 \mathrm{~km}$ and down dip continuity of at least $1 \mathrm{~km}$ have been proved by drilling. A cross - section from north-west to south-east illustrates the irregular topography with various structural lows and bowl shaped areas (Fig. 13). The sheet comes to surface at both ends of the profile.

A preliminary geological model (Fig. 14) was created for the main part of the La Ceniza sheet using the 'Stratmodel' software package (Mincom Pty Ltd, Australia). The model was based on 52 drill holes, a digital terrain model, and a line showing the limit of the mined out area. Footwall contours are oriented north to north-west at the north and south ends of the area but are strongly diverted to the south - west and west in the north-central part of the area, reflecting a well defined structural low, which deepens eastwards. The topographic range is $\sim 25 \mathrm{~m}$ from the low to adjacent structural highs. Note that this area is crossed by an interpreted west north-west trending fault, which has a maximum offset of $16 \mathrm{~m}$, with the south side upthrown relative to the north. Fault offset diminishes to the east south-east, gradually disappearing.

Thickness contours are also shown in Fig. 14 and show a range from $2 \mathrm{~m}$ to $0.5 \mathrm{~m}$. Kimberlite thickness of greater than $1 \mathrm{~m}$ occurs north of the fault and broadly correlates with the structural low. South of the fault most kimberlite is less than 1 $\mathrm{m}$ thick.

Diamond Grade in kimberlite In several areas sample projects were undertaken in conjunction with local diggers who make shafts through the overburden into the weathered kimberlite. The data, while suffering from certain limitations, do provide some indication of the geographical variation of diamond grade.

One sample project was carried out in the La Peinilla area where results showed grades from 0.7 to $3 \mathrm{cts} / \mathrm{t}$. Diamond grade contours are shown in Fig. 15 and tend to show high grade bands oriented parallel to the dip of the sheet. By comparison with footwall contours and thickness contours (see Fig. 12), there is no apparent correlation with sheet topography or thickness. The highest grade contours (greater than $2 \mathrm{cts} / \mathrm{t}$ ) tend to close off in a down dip direction. However, the high grade bands (greater than $1.5 \mathrm{cts} / \mathrm{t}$ ) are open ended in a down dip direction. The distance along strike from maximum to minimum grade is $\sim 50 \mathrm{~m}$. The presence of higher grade bands oriented in a down dip direction is consistent with empirical observations provided by local diggers.

Terminations of kimberlite sheets Data obtained from drilling and miners' workings has now shown that there are zones where the kimberlite sheet fingers out in a series of veins and fractures, only to pick up again after a gap of a few hundred meters, normally at a similar structural level. Between Desayuno and Bicicleta (Fig. 16a) drill hole 59 failed to intersect kimberlite, and it is possible that the Desayuno sheet stopped against a fault between holes 59 and 188. Between Los Indios north and La Lapa (Fig. 16b), drill holes 112 and 113 showed increased fracture counts, but no kimberlite, at the expected intersection zones. There is an elevation difference of approximately $40 \mathrm{~m}$ between Los Indios and La Lapa, only slightly more than the amplitude from structural highs to lows in Los Indios and La Ceniza. Had there been greater magma driving force at the opposing fracture tips, it is likely that they would have connected.

DISCUSSION The role of faulting No evidence for penetrative deformation of kimberlite has been observed. Occasionally a slight fabric is developed at the wall rock contact, reflecting minor syn-or post - emplacement movement. Thin fractures in the adjacent wall are infilled by kimberlite veins or related alteration. The available geological data indicate that any significant vertical or lateral fault movement predated kimberlite emplacement, and that the kimberlite sheets represent a multi - level system and not one single layer, subsequently separated by brittle faulting. The following observations are relevant to this argument:

a) Drilling in the north of Los Indios has intersected first the El Tigre sheet, and then the Los Indios sheet, the two being separated vertically by $68 \mathrm{~m}$.

b) Drilling in Bicicleta and La Ceniza has found kimberlite veins at significant distances above and below the kimberlite sheets, in the case of Bicicleta $107 \mathrm{~m}$ below the Bicicleta sheet.

c) Kimberlite sheets such as Bicicleta and Hueso Duro - La Ceniza show smooth profiles across north - west trending fault zones in the Quebrada Grande valley (see Figs. 7 and 8). Some drill holes in La Ceniza were placed close to the border of the Quebrada Grande valley, which is marked by north - west trending faults, and encountered fractured rock (e.g., drill hole 97-071 with fractured gabbro at 21.8 to $24.3 \mathrm{~m}$ ). The difference in kimberlite elevation between boreholes either side of the fault implies that a maximum of $10 \mathrm{~m}$ of post - kimberlite fault offset has occurred (see Fig. 8b). The Los Indios sheet also shows a smooth profile across north - west trending faults (see section E to E' in Figs. 7 and 9). 


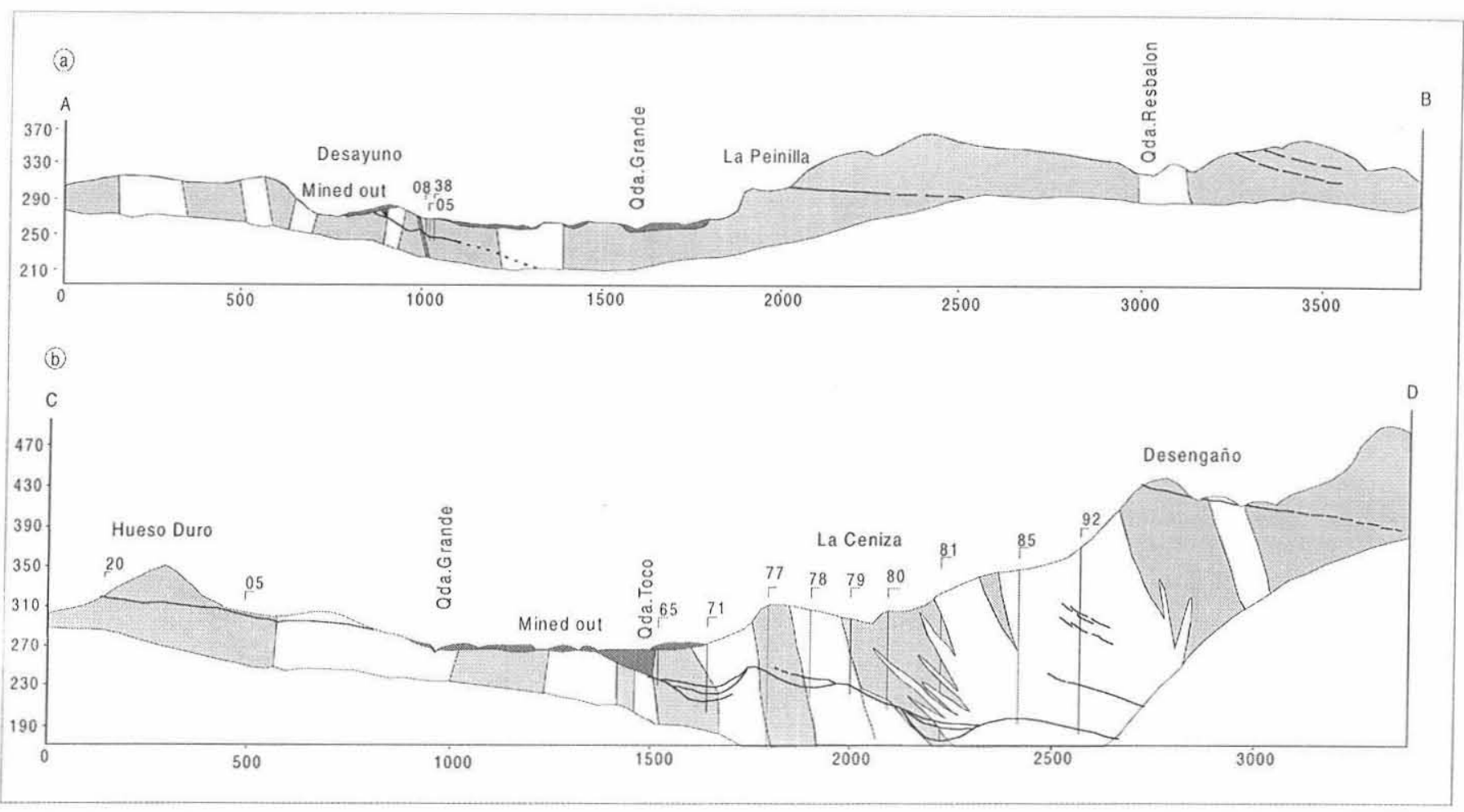

Figure 8-Cross-sections from south-west to north-east, in the north and south of the Quebrada Grande valley. a) Section A - B, showing the Desayuno, La Peinilla, and El Tigre sheets; b) Section C-D, showing the La Ceniza and Desengaño sheets. Locations of section lines and geological legend are shown in Fig. 7. Vertical numbered lines refer to cored drill holes.

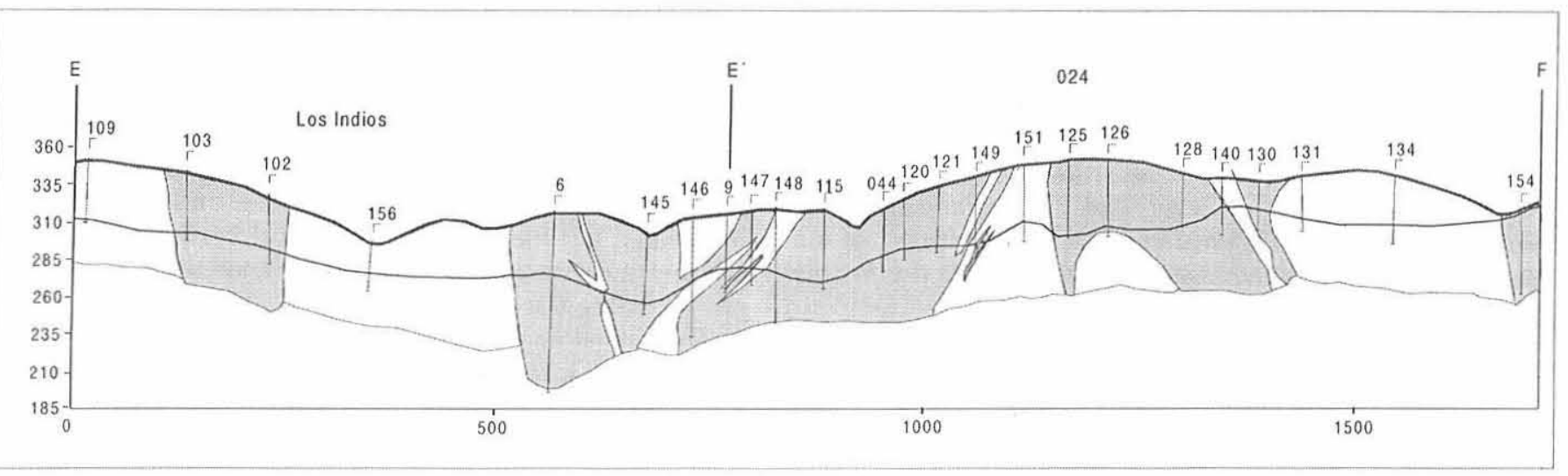

Figure 9 - Cross - section E-E' - F, east-west from E to E', and north-west to south - east from E' to F, along the Los Indios kimberlite sheet. Location of section line and geological legend are shown in Fig. 7. Vertical numbered lines refer to cored drill holes.

d) Within all of the major north - east trending fault zones, continuity of the kimberlite sheets has been proved by drilling (e.g., Desayuno in the Milagro fault zone, Los Indios in the Los Indios fault, and La Ceniza in the La Ceniza fault; see Fig. 7). In La Peinilla there is a significant elevation difference of $\sim 40 \mathrm{~m}$ between the kimberlite on the north and south side of the north - east trending valley (see Fig. 16b) but the distribution of diggers' pits implies that the kimberlite sheet is continuous.

e) In more general terms, it has been shown by Kaminsky et al. $(1998,2000)$ that the very large alluvial diamond resource, now mined out, was derived from eroded kimberlite sheets. These eroded sheets previously extended over the Quebrada Grande and other valleys, consistent with a multi - level system.

Hence, the available data indicate that post-intrusion fault offset of kimberlite sheets is small (i.e., not $>20 \mathrm{~m}$ vertically). Data from La Ceniza (see Fig. 14), for example, imply a maximum displacement of $16 \mathrm{~m}$ over a small distance $(\sim 100$ $\mathrm{m})$, along a west north-west trending fault. Within the north east trending fault zones, the kimberlite sheet geometry is irregular but there does not appear to have been significant postemplacement faulting. It should be noted that there are at least 


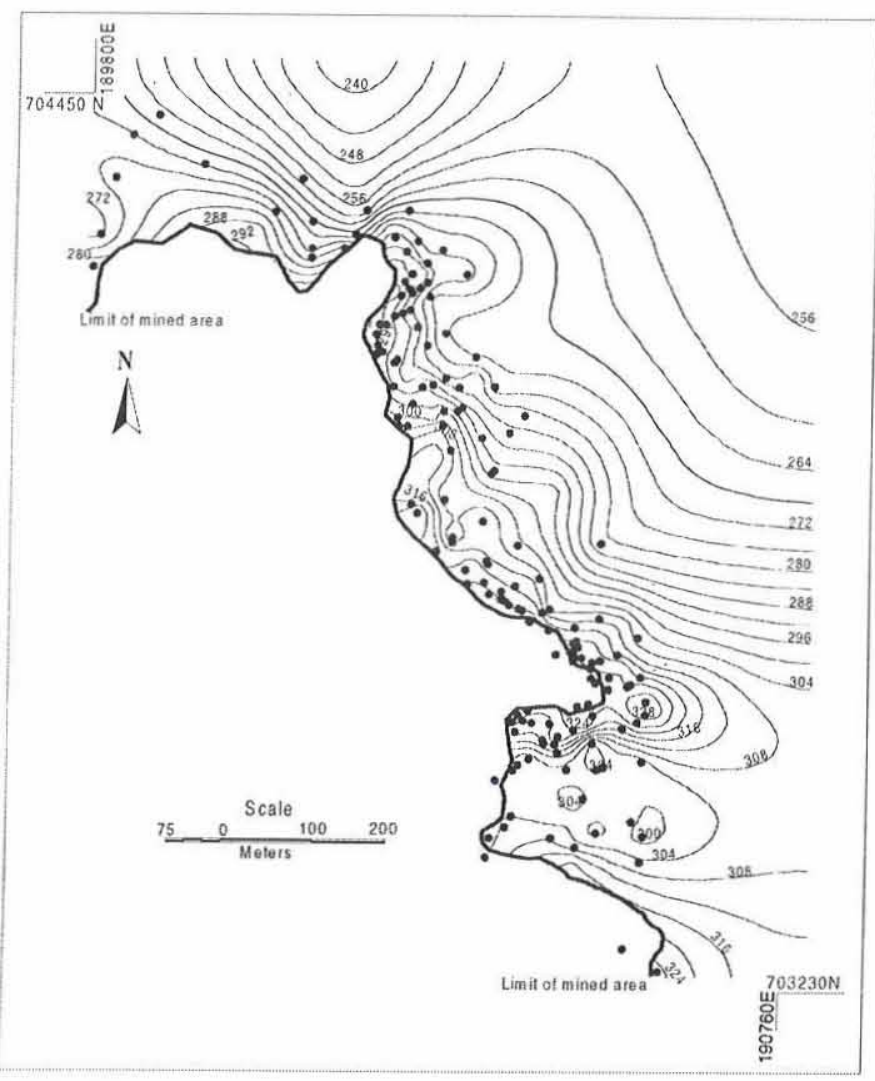

Figure 10 - Geological model of part of the Los Indios kimberlite sheet. The model was generated from 161 borehole intersections (shown as black circles), combined with a digital terrain model and a line showing the limit of mining activities by local diggers. To the west of this line the shallowest kimberlite has been removed either by erosion or by local diggers. Isolated exposures of kimberlite footwall and laterite fragments occur to the west of this line. The position of the line was determined by field measurement of old workings and use of auger holes where necessary. Contour levels are for the footwall and are in meters above sea level.

three levels of alluvial terraces along the Puente Palo valley, occurring over about $15 \mathrm{~m}$ vertically above the bed rock contact. The presence of these terraces shows that some areas within Guaniamo have experienced neotectonic activity.

Mode of emplacement of kimberlite sheets The sheets most likely were emplaced by hydrofracturing, i.e., in fractures whose propagation was driven by magma buoyancy (e.g., Spence \& Turcotte 1988) and pressure. Supporting evidence includes: fracture orientation independent of pre-existing rock fabrics, spaced fractures and veins occurring close to, and sub - parallel with, the kimberlite sheets, abundant veins and fractures at termini of sheets, generally smooth hanging wall and footwall contacts, and localities with high xenolith contents. These characteristics have been observed for other kimberlite sheets (e.g., Andrews \& Emeleus 1975) and diabase sills (Leaman 1995) and sheets (Howard 1991), for which a similar emplacement mechanism was proposed. Prior to kimberlite emplacement in Guaniamo the area had been strongly faulted, forming a block mosaic. It is possible that this

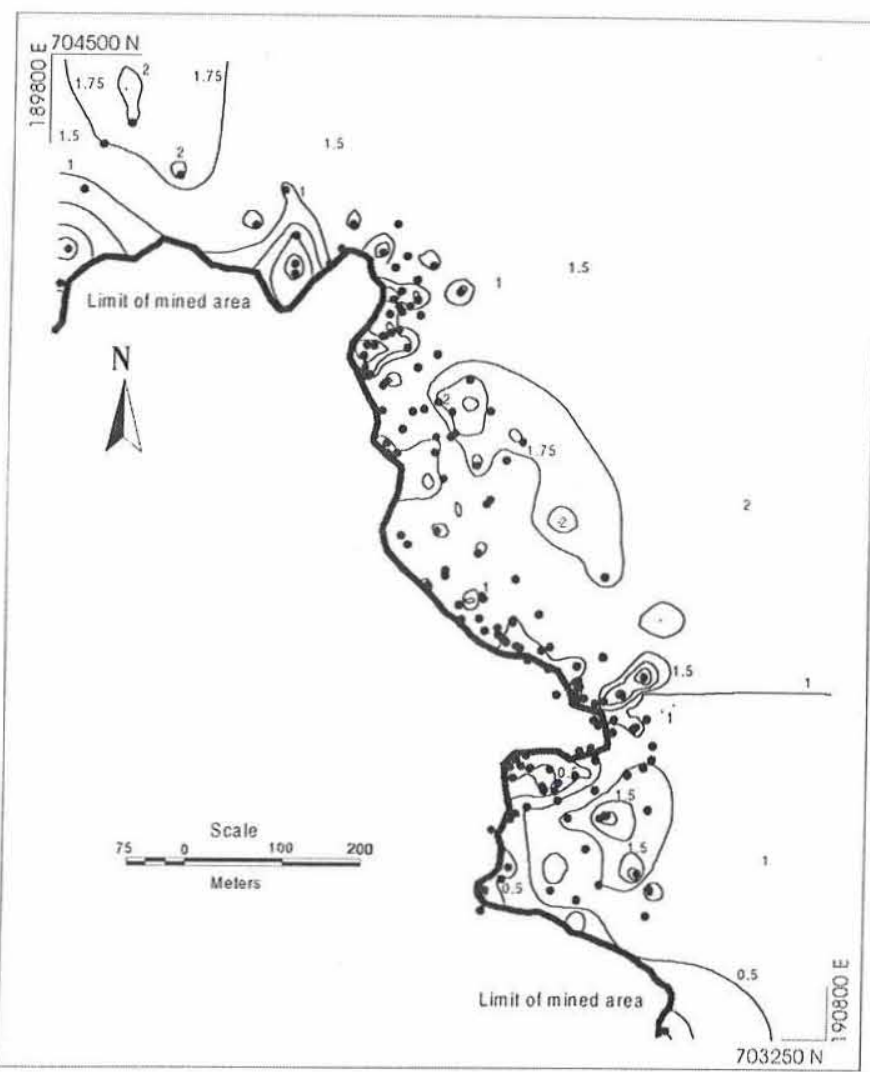

Figure II - Kimberlite thickness model of part of the Los Indios kimberlite sheet. Data were provided from the 161 borehole intersections (shown as black circles). Contour values are in meters.

included the formation of sub - horizontal fractures which were used by the kimberlite magma and earlier mafic intrusions, but the direct geographical correlation between kimberlite sheets and the low angle fractures argues against a pre-existing fracture set.

The kimberlite sheets do not infill a prior joint system. None of the typical textures of joint surfaces have been observed on footwall exposures, and the dimensions of individual sheets are much greater than normal joint dimensions (see Pollard \& Aydin 1988).

Studies of kimberlite sheets in Greenland (Andrews \& Emeleus 1975) showed that the kimberlite only exploited pre - existing fractures, which were of favorable orientation at the time of kimberlite emplacement. There is some evidence for exploitation by kimberlite of previously existing faults. At one locality, near the Puente Palo fault, the kimberlite occurs along an undulating structure, which strikes from $014^{\circ}$ to $089^{\circ}$ and dips at $30^{\circ}-50^{\circ}$ northwards. Steeper faults occur in the hanging wall to the principal structure and appear to derive from it, shallowing as they come closer to it. Kimberlite also occurs along these steeper faults. Given the undeformed nature of the kimberlite, it is likely that it was emplaced along a pre-existing fault and filled available fractures and zones of weakness.

Vertical or sub-vertical feeder dikes have not been observed for the sheets. The Comisario kimberlite, however, has a dip of $\sim 50^{\circ}$ to the south-east and dips into the major north-east trending fault in the area (the Puente Palo fault). This 
kimberlite is the closest candidate for a possible feeder since it connects with the kimberlite sheet at Bulla de las Mujeres, the direction of magma flow being upwards from south - east to north-west. Additional feeders may be located in the other north-east trending faults which occur to the north of the Puente Palo fault (e.g., La Ceniza, Los Indios, Milagro). In order to define the locations of feeders it is very important to know the direction of kimberlite magma injection. If the predominant north-east regional dip of the kimberlite sheets is primary, then the principal direction of magma flow was from north-east to south-west. Imbricated xenoliths at Desengaño and Candado suggest magma flow vectors from east to west. However, a number of observations point to additional flow directions. Several sheets show local pinching out and rising

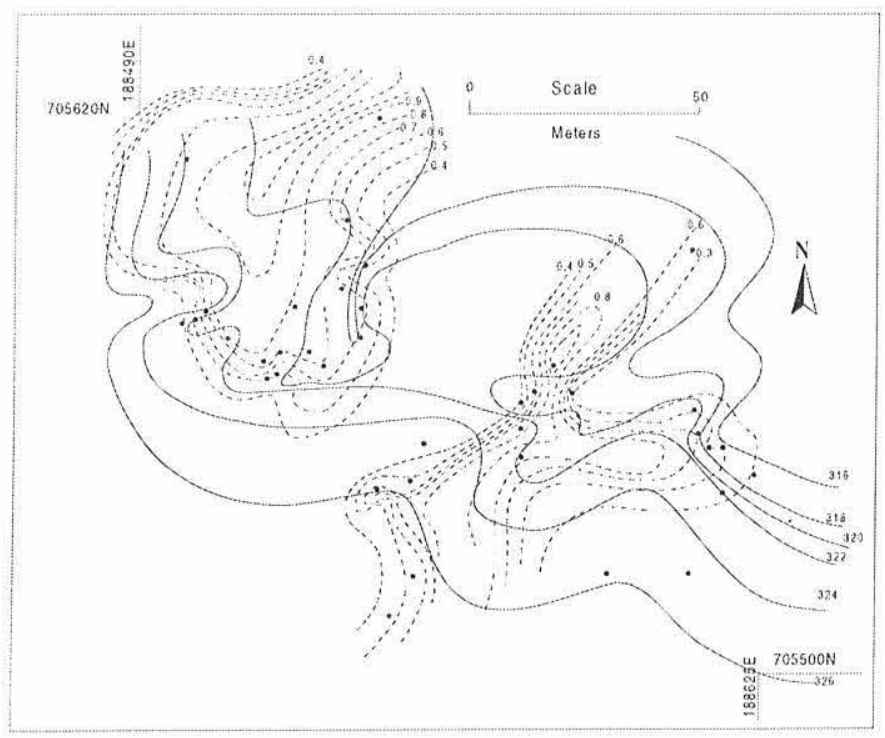

Figure 12 - Contours for kimberlite hanging wall (solid lines, values in meters a.s.l) and kimberlite thickness (dashed lines, values in meters) in La Peinilla. The map was hand contoured based on 46 miners' pits for which pit elevation and depth to kimberlite footwall were measured and for 41 miners' pits for which kimberlite thickness was measured. up to the north and south away from north-east trending fault zones (e.g., La Ceniza, Desayuno, Los Indios, and La Peinilla), implying north - west and north - east directed flows. The gap of about $250 \mathrm{~m}$ between the kimberlite in Los Indios and La Lapa (see Fig. 16b) is consistent with two sheets propagating from the south - east and north - west, respectively, but being sufficiently far from their feeders not to have been able to join up. In Desayuno there are abundant kimberlite fissures that form a circular stockwork $80 \mathrm{~m}$ wide. The concentric inward dip of kimberlite fissures (vertical near the center and then successively flattening out at dip angles of 85 to $25^{\circ}$ ) reveals the shallow focus of the fluid break, possibly only $40 \mathrm{~m}$ below current surface where a blow or feeder should be located. Similar, stockwork zones of kimberlite fissures and alteration were found in Bicicleta. There is a general association of zones of thick kimberlite, greater than $2 \mathrm{~m}$, with structural lows in kimberlite sheets and with north - east trending faults (e.g., Desayuno, Los Indios, Candado, Comisario, and La Ceniza). Thicker kimberlite sheets, with more than one phase of intrusion, would be expected to be more common near to the leeder zones.

These systems of transverse faults superimposed on northwest trending fractures formed zones of weakness or heterogeneity within the crystalline basement, creating fault troughs divided by horst - like structures. The kimberlite sheets appear to have used these fractures, forming embayments in plan view and saucer-or T-shaped (but asymmetrical) bodies in cross section (e.g., Desayuno, La Peinilla, Los Indios, La Ceniza). The lowest topographic points in these embayments are possible feeder dike locations (e.g. this relationship was shown for diabase sheets in Tasmania; Leaman 1995). Using magnetic fabric analysis, Knight \& Walker (1988) found that magma flow directions for Oahu diabase dikes radiated out from several centers, presumably feeders from magma chambers. A similar approach using fresh oriented core would help to resolve this issue in Guaniamo. Currently available data are consistent with the location of feeder dikes in north - east trending faults, with kimberlite magma flowing radially outwards at different levels. For example, localities such as Cordero (point 14 in Fig. 7), which lies in the La Ceniza fault zone, should have been supplied by a feeder dike, which had also supplied the Candado and La Ceniza sheets.

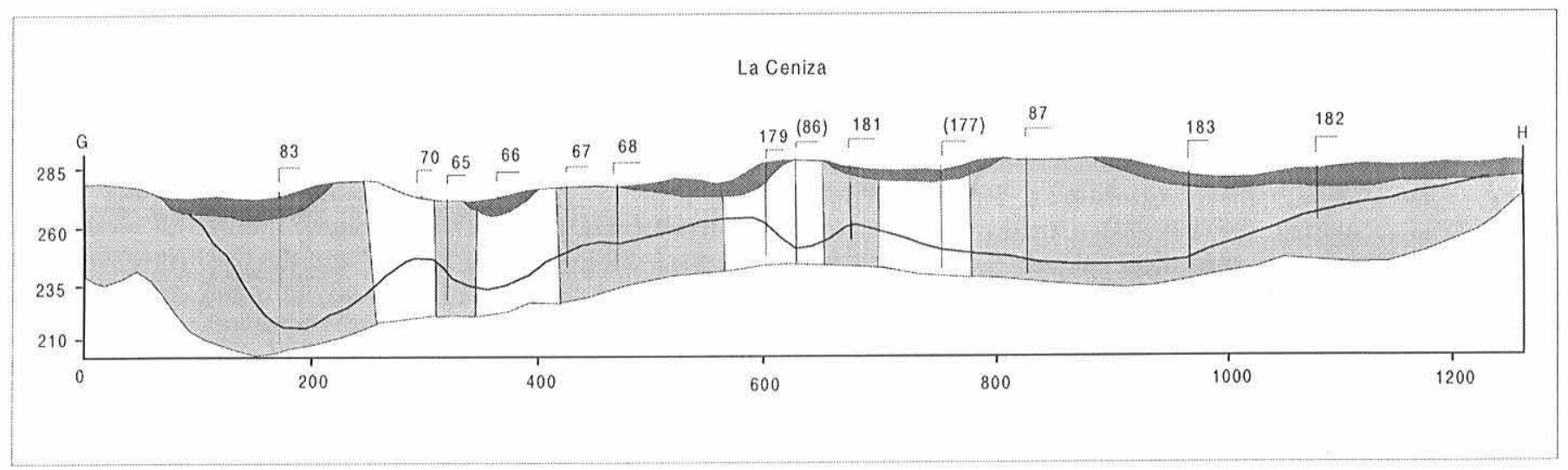

Figure 13 - Cross-section G-H from north-west to south-east, along the La Ceniza kimberlite sheet. Location of section line and geological legend are shown in Fig. 7. Vertical numbered lines refer to cored drill holes. Drill hole numbers in parentheses are off section and in a different lithology. 


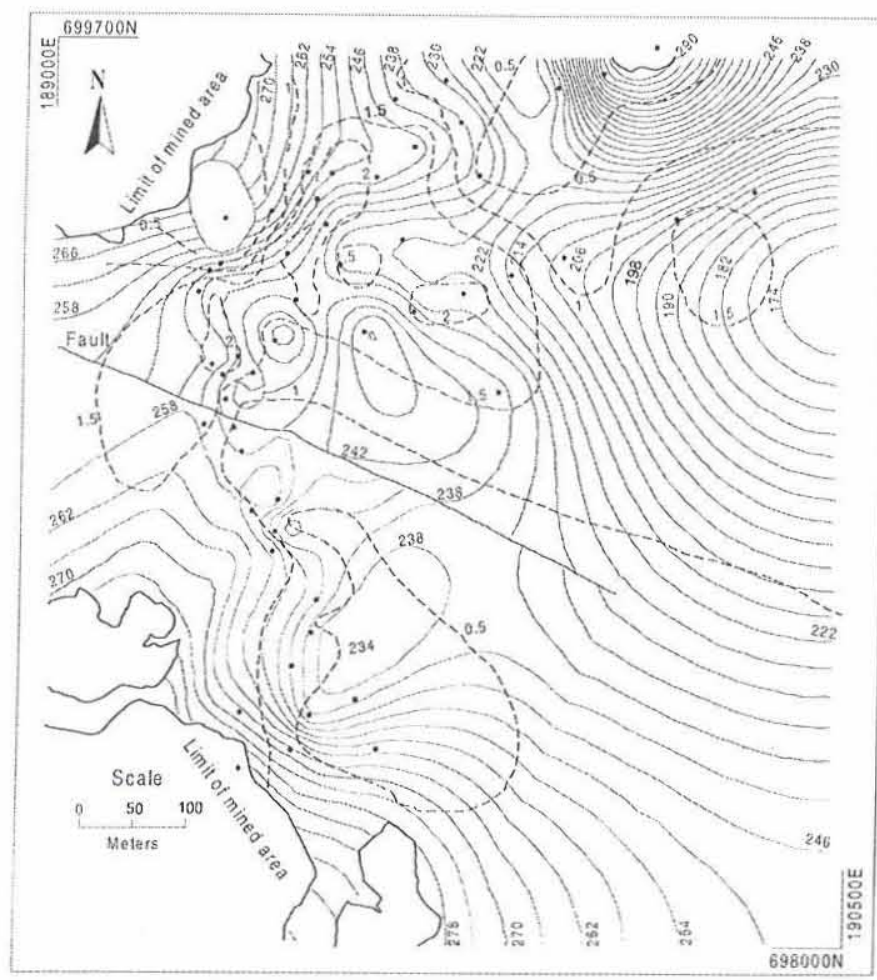

Figure 14 - Preliminary geological model of part of the La Ceniza kimberlite sheet. The model was generated from 52 borehole intersections (shown as black circles), combined with a digital terrain model and a line showing the limit of mining activities by local diggers (see Fig. 4b). For about I km west of this line the shallowest kimberlite has been removed either by erosion or by local diggers. The position of the line was determined by field measurement of old workings. Contour levels are for the footwall and are in meters above sea level.

Comparison with other kimberlite sheets and diabase sheets Andrews \& Emeleus (1975) described kimberlite sheets in Greenland. The structural characteristics show many similarities with Guaniamo. The sheets in Greenland form five, shallow dipping, levels covering a $500 \mathrm{~m}$ vertical interval. The shallow dips appear to be primary. They only exploit older fractures when their orientation is favorable, otherwise they are independent of prior heterogeneities and respond only to the prevailing external stress field at emplacement. Their dip direction may change significantly and the sheet remains continuous (c.f. La Peinilla in Guaniamo). Sheets show evidence for multiple phases of intrusion, for dilation with preservation of screens, for termination against cross - faults, for platy cleavage adjacent to sheet contacts, and for collapse structures in jointed overlying granites. The Greenland sheets have abundant mantle nodules and few local xenoliths, while the reverse is true for Guaniamo. Individual sheets are up to 2 $\mathrm{km}$ in strike length. These similarities imply a similar emplacement mechanism, although the high local xenolith content in Guaniamo suggests more explosive emplacement.

Howard (1991) described middle Proterozoic diabase sheets from the south-west USA, including one example from the Tortilla Mountains where, because of structural tilting, a feeder dike for a diabase sheet is well exposed. The diabase sheets of

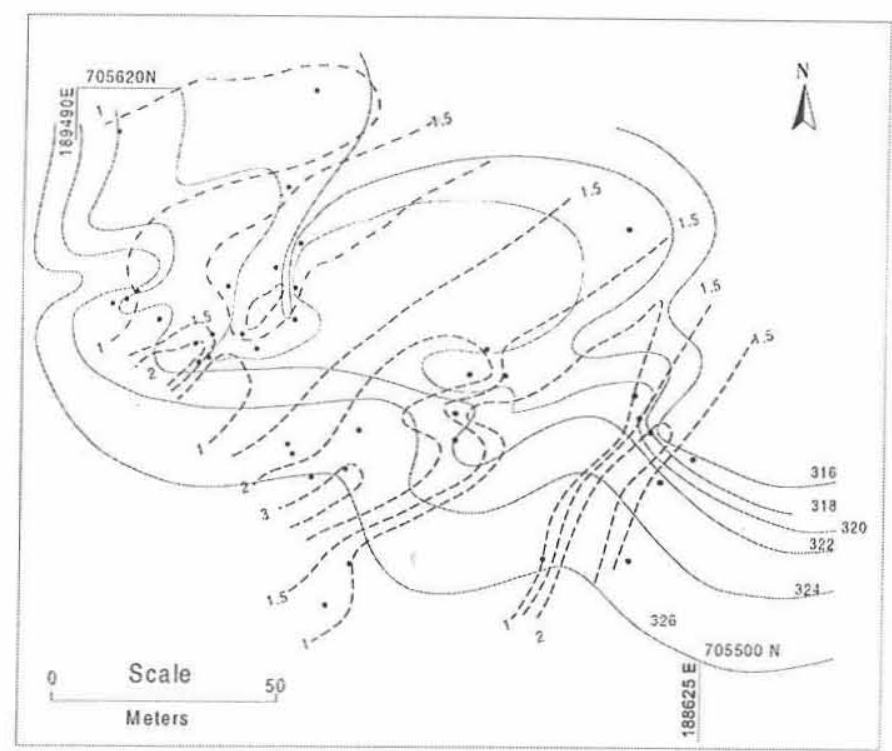

Figure 15 - Diamond grade in the La Peinilla area. The map was hand contoured based on 38 miners' pits for which diamond grade in kimberlite was measured. In total $583 \mathrm{t}$ of kimberlite were processed, giving an average grade of $1.5 \mathrm{cts} / \mathrm{t}$.

the south-west USA occur over $12 \mathrm{~km}$ of crustal section in both basement and overlying sedimentary rocks. By comparison, the kimberlite sheets in Guaniamo have so far been documented over not more than $500 \mathrm{~m}$ of crustal section, probably within $500 \mathrm{~m}$ of the unconformity with Roraima sediments. Stratified mid Proterozoic Roraima formation rocks occur $\sim 30 \mathrm{~km}$ to the south of the area and, assuming no relative displacements, the level of the kimberlite sheets is close to the unconformity between the basement and the sediments. The highest level of kimberlite in the area is about $150 \mathrm{~m}$ below the local topographic high, which is still in basement. Kimberlites could have been emplaced in the Roraima, but the lack of kimberlite sheets in the intervening $150 \mathrm{~m}$ of basement would suggest that it is unlikely for this area. The absence of overlying sediments makes it difficult to know if the shallow eastward dip of the sheets is primary or the result of slight rotation of fault blocks.

In the North - West Territories of Canada, intensive exploration has led to the discovery of hundreds of kimberlite pipes and also kimberlite sheets. The best known is Snap Lake but recently Mountain Province Mining and Tahera Corporation have reported the discovery of kimberlite sheets on their properties.

CONCLUSIONS The Guaniamo kimberlite sheets were intruded into crystalline basement of the Cuchivero group. So far the sheets have been found only in lithotectonic domain I (the Quebrada Grande domain), although diamonds and indicator minerals have been found in domains II and III. In addition, recent exploration has found kimberlite veins just inside domain II near the boundary of domains I and II. These veins occur within a north - east trending fault zone. The kimberlite sheets have exerted a strong influence on local topography in the Quebrada Grande valley, including wide valleys, boulder fields, and slopes.

On a regional scale Guaniamo occurs over thick crust, 


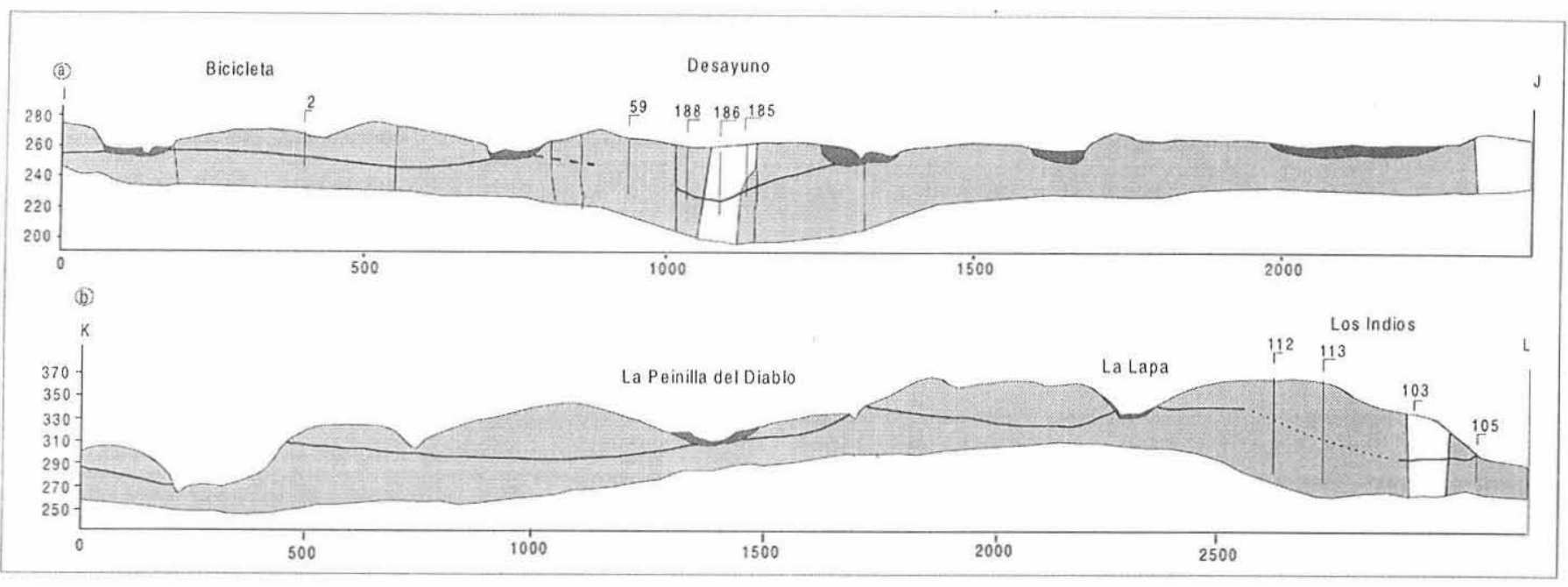

Figure 16 - a) Cross - section I-J from north - west to south-east, along the Bicicleta and Desayuno kimberlite sheets; b) Cross - section K-L from north - west to south - east, along the La Peinilla - Los Indios kimberlite sheet. Locations of section lines and geological legend are shown in Fig. 7. Vertical numbered lines refer to cored drill holes.

within a major rift zone and in an intersection zone with shield scale north - east trending faults. Although the presence of Archean crust beneath the Proterozoic crystalline rocks is not yet proven, the regional setting is otherwise typical for kimberlite.

The Guaniamo kimberlite sheets display structural features typical of other examples, for both kimberlite and diabase. Kimberlite sheets occur over limited vertical intervals $(<1 \mathrm{~km})$ in Guaniamo and Greenland, while diabase sheets cover much larger intervals. They show good evidence for emplacement by magma driven fracture propagation. Imbricated xenoliths, sheet terminations, and zones of steeply dipping kimberlite provide indications of magma flow directions. These appear to be up dip from north - east to south - west, and radially to the north and south away from north - east trending faults. Feeder dikes are most probably located in four major north - east trending fault zones, which cross the north - west structural grain of the area. Kimberlite sheets show structural lows within north - east trending fault zones. Kimberlite sheets show footwall undulations on a 5 to $30 \mathrm{~m}$ scale. In general, the sheets are thinner over structural highs and thicker in lows and outwards from the lows. Grade tends to vary along strike, with no particular correlation with sheet topography or thickness. Textures within kimberlite sheets show that kimberlite was emplaced explosively (xenolith - rich kimberlite) and more quiescently (massive kimberlite). Concentrations of xenoliths or olivine macrocrysts at the base of sheets show that some gravitational settling occurred. In some localities (e.g., La Ceniza) the kimberlite has been offset along later north - west faults with displacements of not more than $20 \mathrm{~m}$. Within the north - east faults kimberlite sheets do not appear to have been offset, although sheet geometry is often irregular.

We suggest that kimberlite magma flowed upwards in the north - east trending fault zones and then radially outwards, with dominant flow to the north-west and south - east. In some cases advancing fractures would have joined, while in others short gaps remain (e.g., between Los Indios and La Lapa). The principal north - east fault zone, the Puente Palo fault, was most likely the most important feeder zone, supplying known kimberlite sheets on its north - west side. Note that diamond indicator minerals have been found to the south of this fault within the younger granites, and also at either end of the Guaniamo section of the fault zone.

An important feature of Guaniamo is the large size and high diamond content of the kimberlite sheet system. This stands in contrast to most other kimberlite sheets, apart from Snap Lake in Canada. In addition, Guaniamo is a multi - level system of kimberlite sheets, distinct from other areas. The increasing number of kimberlite sheet discoveries in Canada, in a region where many kimberlite pipes have already been found due to intensive exploration over a large area, lends support to the contention that more kimberlite sheets and also kimberlite pipes will be found in Venezuela as more exploration is done in a shield area which is relatively under explored for kimberlites.

Acknowledgments We are grateful to Guaniamo Mining Company (Mr. Robert Cooper, President) for permission to present this paper. We are very grateful to Edgardo Torres (Technical Drafting) and José Uzcátegui (Geological Drafting) for their patient and careful work on drafting of figures. We acknowledge previous geologists with Guaniamo Mining Company, who have contributed to the acquisition of the information presented in this contribution. Also we thank to the reviewers from RGB for the suggestions to the manuscript. 


\section{References}

Andrews J.R. \& Emeleus C.H. 1975. Structural aspects of kimberlite dike and sheet intrusion in south-west Greenland. Phys. Chem. Earth, 9:43-50.

Añez G. 1985. Exploración y Evaluación de posibles depósitos diamantíferos en el Distrito Cedeño del Estado Bolívar. Memoria I, Simposio Amazónico, Boletín de Geología, Publicación Especial №10, Ministerio de Energía y Minas. Dirección de Geología, 443-463.

Baptista G.J. \& Svisero D.P. 1978. Geología de los depositos diamantíferos de la parte norooccidental de la Guayana Venezolana. Republica de Venezuela, Ministerio de Energía y Minas, Dirección General Sectorial de Minas y Geología XIII (24) (Agosto, 1978), 3-46.

Bizzi L.A., Smith C.B., de Wit M.J., Armstrong R.A., Meyer H.O.A. 1991. Mesozoic kimberlites and related alkalic rocks in the south - western Sao Francisco craton, Brazil: a case for local mantle reservoirs and their interaction. Proceedings of the $5^{\text {th }}$ International Kimberlite Conference, Brazil, v.1., 156-171.

Channer D.M.DeR. \& Cooper R.E. 1997. The Guaniamo diamond region, Bolivar state, Venezuela: a new kimberlite province. Memorias del VIII Congreso Geológico Venezolano, Soc. Venezolana de Geol. Tomo I, Nov. 1997, p. 143-146.

Channer D.M.DeR., Cooper R.E., Kaminsky F.V. 1998. The Guaniamo diamond region, Bolivar State, Venezuela: A new kimberlite province. Extended Abstracts, $7^{\text {th }}$ International Kimberlite Conference, Cape Town, South Africa, April 1998, 144-146.

Channer D.M.DeR. \& Anderson P.F.N. 2000. Volcanogenic massive sulphide occurrences and potential in Venezuela, with emphasis on the Guayana shield. In VMS deposits of Latin America, Geological Association of Canada Special Publication No. 2, eds. Sherlock, R. and Logan, M.A., p. 293-313.

Curtis G.E. 1975. Venezuela's Valley of Diamonds: El Guaniamo Diamond Shout. Lapidary Journal, February 1975, 1708-1718.

Díaz R. 1977. Variación vertical y lateral de ocho perfiles aluvionales de la Qda. Grande, afluente del río Guaniamo, comprendidos entre los campos mineros La Bicicleta, La Salvación, Distrito Cedeño, Edo. Bolívar. Cong. Geol. Venz. V. Memoria Tomo III. p.957-988.

Gaudette H.E., Mendoza V., Hurley P.M., Fairburn H.W. 1978. Geology and age of the Parguaza rapakivi granite, Venezuela. Geol. Soc. Am. Bull., 89:1335-1340

Gaudette H.E. \& Olszewski W.J. 1985a. Determination of radiometric ages, Amazonas territory, Venezuela. Memoria I Simposio Amazónico, Puerto Ayacucho, Venezuela. Boletín de Geología, Publicación Especial 10, 733 746.

Gaudette H.E. \& Olszewski W.J. 1985b. Geochronolgy of the basement rocks, Amazonas territory, Venezuela, and the tectonic evolution of the western Guiana shield. Geologie en Mijnbouw, 64:131-143.

Gibbs A. K. \& Barron C. N. 1983. The Guiana shield reviewed. Episodes, No. 2, 7-14.

Gibbs A. K. \& Barron C. N. 1993. Geology of the Guiana shield, Oxford University Press, 246p.

Hawthorne J.B. 1968. Kimberlite sills. Trans. Geol. Soc. S. Africa, 71:291-311.

Howard K.A. 1991. Intrusion of horizontal dikes: Tectonic significance of Middle Proterozoic Diabase sheets widespread in the upper crust of the southwestern United States. Jnl. Geophys. Research. 96, B7:12461-12478.

Kaminsky F.V., Sablukov S.M., Sablukova L.I. 1997. Results of a petrographic, mineralogical, and geochemical study of kimberlites from the Los Indios and Desayuno sills, Guaniamo area, Venezuela. Report for Guaniamo Mining Company.

Kaminsky F.V., Zakharchenko O.D., Channer D.M.DeR., Blinova G.K., Maltsev K.A. 1998a. Diamonds from the Guaniamo area, Bolivar state, Venezuela. Extended abstract, 7th International Kimberlite Conference, Cape Town, April 1998, p.395-397.

Kaminsky F.V., Sablukov S.M., Sablukova L.1. 1998b. Results of a petrographic, mineralogical, and geochemical study of kimberlites from the La Ceniza sill, Guaniamo area, Venezuela. Report for Guaniamo Mining Company.

Kaminsky F.V., Zakharchenko O.D., Griffin W.L., Channer D.M.DeR., Khachatryan-Blinova G.K. 2000. Diamond from the Guaniamo area,
Venezuela. Can. Mineral., 38:1347-1370.

Knight M.D. \& Walker G.P.L. 1988. Magma flow directions in dikes of the Oahu Complex, Oahu, determined from magnetic fabric studies. Jnl. Geophys. Research. 93, B5:4301-4319.

Leaman D.E. 1995. Mechanics of sill emplacement: comments based on the Tasmanian dolerites. Aust. Jnl. Earth. Sci, 42:151-155.

Martin-Bellizia C. 1972. Paleotectónica del Escudo Guayana. IX Conferencia Geológica Inter-Guayanas, Ciudad Guayana, Venezuela, 1972. Boletín de Geología, Publicación Especial 6, 251-305.

Mendoza V. 1972. Geología del área del Río Suapure NW del Escudo de Guayana, parte noroccidental del escudo de Guayana, Edo. Bolívar, Venezuela (Informe de progreso). IX Conferenia Geológica Inter-Guayanas, Ciudad Guayana, Venezuela. Boletín de Geología, Publicación Especial 6, 306-338.

Mendoza V. 1975. Estudios geoquímicos del no-tectonizado granito rapakivi del Parguaza, noroeste Guayana Venezolana. Anais X Conferencia Geológica Interguayanas, Belem, Pará, Brasil, 628-656.

Menéndez V. 1968. Revisión de la estratigrafía de la Provincia de Pastora según el estudio de la región de Guasipati, Guayana Venezolana. Boletín de Geología, Caracas, 10, N. 19, 309-338.

Meyer H.O.A. \& McCallum M.E. 1993. Diamonds and their sources in the Venezuelan portion of the Guyana Shield. Econ. Geol., 88:989-998.

Moser D.E. 1996. Report on Rb-Sr and U-Pb geochronology of kimberlite sample GLI and granite sample Guan-1. Report for Guaniamo Mining Company.

Nixon P.H. 1988. Diamond source rocks from Venezuela. Indiaqua, 51:23-29.

Nixon P.H., Davies G.R., Rex D., Gray A. 1992. Venezuela kimberlites. Jour. Volcan. Geoth. Res., 50:101-115.

Nixon P.H., Griffin W.L., Davies G.R., Condliffe E. 1995. Cr garnet indicators in Venezuela kimberlites and their bearing on the evolution of the Guayana craton. In: Kimberlites and related rocks (H.O.A. Meyer and O.H. Leonardos, eds.). Vol. 1, Brasilia, 378-380.

Olmeta M.A. 1968. Determinación de edades radiométricas de rocas de Venezuela. Boletín de Geología, Caracas, 10, № 19.

Pollard D.D. \& Aydin A. 1988. Progress in understanding jointing over the past century. Geol. Soc. Amer. Bulletin. 100:1181-1204.

Reid A.R. 1974. Proposed origin for Guianian diamonds. Geology, 2:67-68.

Ríos J.H. 1969. Geología de la Región de Caicara, Edo. Bolívar. IV Congreso Geológico Venezolano, Boletín de Geología, Publicación Especial 5, 17591782.

Sidder G.B. \& Mendoza V. 1995. Geology of the Venezuelan Guayana shield and its relation to the geology of the entire Guayana shield. U.S. Geological Survey Bulletin 2124, B1-B41.

Skinner E.M.W., Vildjoen K.S., Clark T.C., Smith C.B. 1991. The petrography, tectonic setting, and emplacement ages of kimberlites in the south western border region of the Kaapvaal craton, Prieska area, South Africa. Proceedings of the $5^{\text {th }}$ International Kimberlite Conference, Brazil, v.1., 8097.

Sobolev N.V., Efimova E.S., Channer D.M.DeR., Anderson P.F.N., Barron K.M. 1998. Unusual upper mantle beneath Guaniamo, Guayana Shield, Venezuela: evidence from diamond inclusions. Geology, 26:971-974.

Spence D.A. \& Turcotte D.L. 1990. Buoyancy-driven magma fracture: A mechanism for ascent through the lithosphere and the emplacement of diamonds. Jnl. Geophys. Research. 95, B4:5133-5139.

Svisero D.P. \& Baptista G.J. 1973. Inclusiones en los diamantes de la Quebrada Grande, Distrito Cedeño, Estado Bolívar, Venezuela. In : II Congr. Lat. Amer. Geol., Caracas, 1973, Resumenes, 158-160.

Tassinari C.C. \& Macambira M.J. 1999. Geochronological provinces of the Amazonian craton. Episodes, 22:174-182.

York D. 1996. ${ }^{40} \mathrm{Ar} /{ }^{39} \mathrm{Ar}$ analysis of kimberlitic phlogopite from Guaniamo. Report for Guaniamo Mining Company.

Manuscrito A-1315 Recebido em 07 de dezembro de 2001 Revisão dos autores em 22 de dezembro de 2001 Revisão aceita em 23 de dezembro de 2001 